\title{
Um soldado na frente de batalha, um cientista no laboratório. A vanguarda de Aleksandr Rodchenko entre a cultura visual e a cultura política'
}

\section{Erika Zerwes ${ }^{2}$}

RESUMO: Este artigo busca retomar o período anterior à adoção da fotografia como meio artístico privilegiado por Aleksandr Rodchenko (1891-1956), por entender que a fotografia significou não uma ruptura, mas, ao contrário, fez parte de uma experimentação visual mais abrangente que ele conduziu na década de 1920. Busca-se também recolocar esta produção artística dentro da cultura política com a qual travou um constante e íntimo diálogo.

Ao refazer os caminhos que levaram Rodchenko da pintura à fotografia, buscamos assim melhor compreender e detalhar o compromisso político que animou a produção artística da época, e a de Rodchenko em particular, entendida então como uma práxis política e social mais ampla, da qual a fotografia foi uma das partes constitutivas.

PALAVRAS-CHAVE: Aleksandr Rodchenko. Vanguarda russa. Cultura política. Cultura visual. Fotografia.

ABSTRACT: This paper intends to retrace the early years before Aleksandr Rodchenko 11891 1956) adopted photography as a main artistic expression, process which is understood not as a rupture, but as a part of a larger visual experiment that he was developing during the 1920s. It also intends to place this artistic production in the realms of a political culture with which it was in constant and close dialogue.

In retracing Rodchenko's paths from painting to photography, this paper intends to better comprehend and detail the political commitment behind that artistic production, and Rodchenko's in particular, which were understood as a broader political and social praxis that had photography as one of its constitutive parts.

KEYWORDS: Aleksandr Rodchenko. Russian avant-garde. Political culture. Visual culture. Photography.
1. A pesquisa que resultou neste artigo teve apoio financeiro da FAPESP.

2. Pós-Doutoranda no MACUSP. Doutora em História pelo IFCH-UNICAMP (2013). Email: <ezerwes@ hotmail.com>. 
3. Cf. Alfred H. Barr Jr. (1978, p. 21).

4. Ver Leah Dickerman (1997, p.12).

5. Ver Alfred Barr Jr. (1989, p. $99-100 ; 160)$.

6. Seria anos depois este mesmo museu, no entanto, que viria a revisitar esta história, especialmente no livro que editou com os escritos completos do artista - ver Alexander Lavrentiev (2005) e um catálogo com 318 imagens e cinco ensaios de alguns dos maiores pesquisadores de sua obra Peter Galassi; Magdalena Dabrowski e Leah Dickerman (1999) -, após a grande retrospectiva apresentada em 1998, Aleksandr Rodchenko, uma das maiores exposições voltadas à obra deste artista já montadas no ocidente.

7. Cf. Douglas Crimp (2005, p. 232).
A obra de Rodchenko e o ocidente

O trabalho de Rodchenko, bem como de boa parte da vanguarda soviética, ganhou maior visibilidade no ocidente por meio de Alfred Barr Jr. Este, que a partir de agosto de 1929 passou a ser o primeiro diretor do Museu de Arte Moderna de Nova York, o MoMA, havia estado entre os meses de dezembro de 1927 e fevereiro de 1928 na Rússia, visitando artistas da vanguarda e suas obras. Em 3 de janeiro de 1928, esteve na casa de Rodchenko, tomando conhecimento de suas pinturas, pôsteres, construções tridimensionais, design de livros e fotografias. $\mathrm{Na}$ entrada correspondente a este dia, Barr escreveu em seu diário que considerou Rodchenko e sua esposa, Varvara Stepanova, "artistas brilhantes, versáteis", e que tomou providências para ter fotografias do trabalho daquele para um artigo ${ }^{3}$.

Alguns anos mais tarde, Barr organizou no museu nova-iorquino a exposição Cubism and Abstract Art, aberta ao público em 1936, na qual constavam algumas pinturas de Rodchenko. Leah Dickerman ${ }^{4}$ chamou a atenção, ao mesmo tempo, para a importância da visita de Barr à Rússia, ainda fervilhante com os efeitos da Revolução de Outubro, e para o tom, até certa forma despolitizado, com que as obras da vanguarda russa, em especial o Construtivismo, foram tratadas nesta exposição - apontadas no famoso esquema que desenhou para seu catálogo como descendentes diretas do cubismo ${ }^{5}$.

Não obstante, pode-se dizer que esta viagem de Barr à Rússia soviética foi um marco para o contato entre o ocidente e a arte de vanguarda russa, em especial para nós, com a arte de Rodchenko. Embora tenha muito mais nuances do que poderíamos aqui detalhar, a mediação institucional do MoMA nestas primeiras décadas de sua existência deixou marcas na relação entre a crítica e as obras de Rodchenko ${ }^{\circ}$. Não apenas Dickerman, como antes dela também Douglas Crimp, havia chamado a atenção para o tratamento expositivo dado pelo museu nova-iorquino a estas obras, que as destacava de seu âmbito sócio-político mais abrangente.

Segundo Crimp, um golpe duplo teria sido desferido nesta vanguarda ao ser incorporada naquele museu. Em primeiro lugar, a própria presença desses objetos - muitos dos quais concebidos para serem utilitários -, dentro de um museu de arte seria uma capitulação frente a todo o processo de crítica da arte tradicional realizada nos anos de 1920. No MoMA, a vanguarda estaria no mesmo local institucional da arte que eles tentaram destruir; no mesmo pedestal burguês que eles pretenderam deslegitimar; as obras da vanguarda teriam sido "domesticadas" aspecto da conformação da vanguarda ao museu seria igualmente prejudicial à sua correta compreensão histórica, e diz respeito à fragmentação desta obra nos diversos rótulos das seções do MoMA. O caso de Rodchenko é exemplar, pois ele transitou por diversos meios, desde a pintura, a escultura, até o cartaz, a fotomontagem e a fotografia, e, como se verá a seguir, todas essas obras estavam interligadas dentro de uma experimentação visual mais abrangente. Crimp afirma que quando o museu separou a produção de Rodchenko em departamentos diferentes e estanques como 
os de Pintura e Escultura, Desenhos, Arquitetura e Design, Fotografia, e etc., ele teria optado por "construir uma história formalista do modernismo"8. A experimentação visual teria se esvaziado, e perdido imediatamente sua ligação com a cultura política que a animava, e com a qual estava em diálogo próximo?.

$\bigcirc$ cerne da questão estaria, portanto, na integridade de sua obra enquanto um processo experimental continuado - do qual a fotografia seria um dos elementos constitutivos. A crítica, no entanto, por algum tempo insistiu igualmente em uma leitura tanto fragmentada quanto dissociada das principais características políticas da produção artística de Rodchenko.

$\bigcirc$ turbulento período do stalinismo, e mais tarde da Guerra Fria, teriam aprofundado esta visão mais despolitizada, segundo Margarita Tupitsyn, também na União Soviética. A autora elaborou tal posição partindo da contribuição de um importante historiador da arte, Sergei Morozov, que, em 1958, publicou a primeira pesquisa sobre a história da fotografia russa na era pós-stalinista, Sovetskaia khudozhestvennaia fotografiia [Arte fotográfica soviética].

Nesta obra, que também se tornou fonte para os primeiros pesquisadores ocidentais da fotografia russa, Morozov teria optado por estabelecer uma leitura das imagens fotográficas a partir de parâmetros da pintura e da arte tradicional, deixando de lado seu conteúdo político, como estratégia para que não houvesse censura ou represálias políticas sobre seu estudo, uma vez que a vanguarda da década de 1920, a partir da subida de Stálin ao poder, foi renegada e perseguida ${ }^{10}$. Deste modo, Morozov, ao mesmo tempo em que teria retirado do esquecimento os fotógrafos e a fotografia soviética, também teria corroborado uma tradição de interpretação apolítica dessas imagens.

Em língua inglesa, uma das primeiras publicações teóricas sobre a vanguarda russa é de Camilla Gray, que na década de 1960 escreveu The Great Experiment: Russian Art 1863-1922, enquanto manteve contato com Barr ${ }^{11}$. Gray também adotou o tom despolitizado, e encerrou sua obra pioneira com a produção da vanguarda em 1922, dois anos antes de Rodchenko ter começado a fotografar, em 1924. Quase duas décadas depois de Gray, a também norte-americana Christina Lodder tomou para si a tarefa de acompanhar os passos da vanguarda russa da primeira metade do século XX, e é dela a obra de mais fôlego sobre o assunto, Russian Constructivism, de 198712. Lodder analisou os artistas e a produção da vanguarda dentro dos desenvolvimentos políticos e das instituições estatais responsáveis por eles, dando assim uma compreensão mais abrangente desse movimento. Ela ateve-se, no entanto, ao período anterior à formação do grupo LEF, de 1923, e assim também não chegou a abordar com mais demora a fase em que Rodchenko se dedicou à fotografia.

Sobre a fotografia russa de vanguarda, referência importante é a tese - depois lançada em livro - Beyond Formalism: The Function of the Soviet Photograph: 1924-1937, da russa radicada nos Estados Unidos Margarita Tupitsyn ${ }^{13}$. Ela estudou os principais fotógrafos vanguardistas, mas também alguns dos fotógrafos de destaque que defendiam a estética realista, e suas filiações
8. Cf. Ibidem (p. 234).

9. Ver Ibidem (234-235).

10. Ver Margarita Tupitsyn (2000).

11. Ver Camilla Gray (2000).

12. Ver Christina Lodder (1987).

13. Ver Margarita Tupitsyn (1996). 
14. Cf. Margarita Tupitsyn (1996 p. XIV).

15. Ver Leah Dickerman (1997).

16. Ao me referir ao grupo LEF, a grafia será em caixa alta, ao contrário, porém, ao me referir à revista do grupo, Lef, o farei em itálico.

17. Ver, em especial, Annateresa Fabris (2006).

18. Cf. Walter Benjamin (1995, p. 32).

19. Esse artigo faz parte de um estudo mais ampliado que tematiza a produção fotográfica de Rodchenko. Ver Erika Zerwes (2008). políticas. Sobre Rodchenko, no entanto, ela afirmou que, ao contrário de colegas como Gustav Klutsis ou Sergei Senkin, que produziam fotografias e fotomontagens com temas políticos, as obras dele não teriam tal orientação, seriam as "...less politically oriented works of Rodchenko"14. Segundo ela, esta orientação política estaria necessariamente ligada a uma orientação partidária.

O alemão Selin $\bigcirc$. Khan-Magomedov produziu um importante estudo sobre a biografia, bem como sobre toda a carreira artística de Rodchenko. Seu Rodchenko: The Complete Work, de 1986, é referência fundamental. KhanMagomedov possui muitos documentos sobre Rodchenko, e publicou-os nessa obra - porém nem todos e alguns somente em partes.

Sobre o trabalho de Rodchenko no período específico em que priorizou a fotografia, importante contribuição é o estudo de Leah Dickerman, Aleksandr Rodchenko's Camera-Eye: Lef Vision and the Production of Revolutionary Consciousness ${ }^{15}$. Neste trabalho de 1997 ela se ateve de forma minuciosa à relação entre o artista e o grupo LEF (Frente Esquerda das Artes), depois renomeado Novyi LEF (Novo LEF)16, do qual Rodchenko foi membro importante durante toda sua duração, de 1923 a 1925 e depois de 1927 a 1928.

Aqui no Brasil destacamos a análise que Annateresa Fabris faz da obra de Rodchenko. Especialmente em Um olhar sob suspeita, Fabris analisa as tensões estéticas e ideológicas que pautaram a atuação de Rodchenko como fotógrafo na passagem para o período stalinista dos primeiros anos da década de $1930^{17}$.

Alinhada a esta crítica mais recente, que acredita na possibilidade de uma pesquisa histórica que procure a militância das palavras dentro das imagens, a análise aqui proposta se atém ao período anterior à adoção da fotografia como meio de expressão privilegiado por Rodchenko, mas a todo momento a leva em consideração e the faz referência, na tentativa de não segmentar esta produção fotográfica de sua produção artística. Ao contrário, toma-a como parte de um projeto imagético que anda junto com uma ação política. Dentro de sua obra imagética e de seus escritos há a indicação de uma mútua aderência: os escritos refletindo sobre a composição estética e as imagens comunicando sua filiação política. $\bigcirc$ intuito é transformar as imagens em documentos sem, no entanto, trair o desejo e a liberdade criativos do artista ao elaborá-las.

Concorrem para a feitura de uma obra artística muitos fatores, que nem sempre podem ser historicamente avaliados, por serem subjetivos. Assim, o pedestal sagrado da obra de arte, tanto sublime quanto etérea - que Rodchenko jamais desejou - não pode acompanhar a leitura dessas imagens. Como disse Benjamin, "Obras de arte mantêm-se longe uma da outra pela perfeição", porém "conteúdo e forma são na obra de arte um só: teor" ${ }^{\prime \prime}$. De certa forma, a arte moderna depois de Duchamp trouxe confusão ao fruir o estético, embaralhando as categorias, a começar pela própria ideia de obra de arte. A imagem técnica, devido a suas características intrínsecas, como a falta da aura benjaminiana, está no cerne deste debate. Daí a necessidade de transformá-la em documento, desmontá-la, comparála, analisá-la ${ }^{19}$. 
Mesmo imerso em uma guerra civil, com o poder dos bolcheviques ainda não totalmente consolidado, nos primeiros doze meses que se seguiram à Revolução de Outubro de 1917, Lênin (1870-1924) promulgou não menos do que duzentos decretos e resoluções concernentes à cultura ${ }^{20}$. Tal quantidade ajuda a traçar as aproximações entre arte e política na Rússia do início do século XX, uma vez que indica que a preocupação governamental com as manifestações artísticas remete às origens do próprio Estado socialista.

De fins de 1917 até o início de 1921 , a Rússia viveu internamente o chamado período de Comunismo de Guerra, um estado de guerra civil iniciado após as desapropriações das terras, em que lutaram o governo socialista e os seus contrários, apoiados pelos Estados Unidos, França e Inglaterra. Ao final do conflito, - Partido Bolchevique, que passou a se chamar Partido Comunista, assumiu efetivamente o poder, com Lênin à sua frente, tendo que gerir não só o saldo de vinte e dois milhões de mortos, somente nesse conflito, como também um país economicamente dilacerado, embora com a socialização completa dos meios de produção. Assim, em fevereiro de 1921 foi criada a Comissão Estatal de Planificação Econômica ou GOSPLAN, e em março foi posta em prática a NEP, a Nova Política Econômica, na tentativa de reorganizar a economia, retomando a produção praticamente estagnada. Na prática, a NEP, que durou de 1921 a 1928, permitiu a volta de pequenos empreendimentos e propriedades privados, enquanto que as grandes fazendas e empresas continuavam estatizadas sob os moldes socialistas.

$\bigcirc$ período em que vigorou a NEP foi também o período em que movimentos de arte de vanguarda tomaram corpo dentro da Rússia. Apesar da situação de relativa estabilidade econômica e social ter possibilitado o florescimento de tais manifestações artísticas - no geral de cunho moderno e em diálogo com parte da produção europeia - as bases dos grupos de vanguarda estavam localizadas anteriormente, nos anos imediatamente anteriores à Revolução, e nos momentos imediatamente posteriores, em que o socialismo ainda lutava para se estabelecer. Estes movimentos revelaram seu engajamento político já na forma com que se intitularam: colocaram-se à frente de seus pares, no âmbito da arte, utilizando um termo retirado de declarações políticas de Lênin desde 1902, em que afirmava que o então Partido Bolchevique, depois Comunista, seria a "vanguarda das forças revolucionárias em nossos tempos" 21 . A noção de vanguarda passou, com a arte moderna, a ocupar um território privilegiado na confluência entre arte e política ${ }^{22}$.

As origens do termo, porém, têm conotação eminentemente bélica, tornando-o ainda mais propício a ser usado pelas vanguardas russas, engajadas na luta pelo estabelecimento do socialismo, e em seguida na construção da nova sociedade que o abrigaria. Da mesma forma que a arte adentrou o âmbito da política, para o Partido Comunista ela possuía o sólido propósito de educar as massas da população russa de acordo com os preceitos por ele determinados, e
21. Cf. Donal Drew Egbert (1967, p. 339-366). Segundo o autor, Lênin afirmou, em 1902, em What is to be done?, que o partido seria a "vanguarda das forças revolucionárias de nosso tempo" usando a palavra avangard.

22. Ver Jacques Rancière (2005). 
23. Cf. Donald Drew Egbert (1973, p. 60). Esta frase ganhou muito destaque pois foi usada como lema do Congresso Internacional de Cultura Proletária de 1930, durante o pleno vigor dos expurgos stalinistas.

24. [Levyi front iskusstv]. O LEF foi um grupo de intelectuais e escritores vanguardistas associados a Maiakovski, que buscaram o lugar da arte e do artista dentro do comunismo. Além do poeta, assinaram o manifesto do grupo $\mathrm{N}$. Aseiev, B. Arvatov, O. Brik, B. Kushner, S. Tretiakov, N. Chuzhak. A. Rodchenko e V. Chclóvski, os quais foram membros atuantes. $\mathrm{O}$ grupo publicou uma revista, de mesmo nome, entre 1923 e 1928. Lef teve sete edições, entre março de 1923 e janeiro de 1925 . Era dividida em seções, entre elas "teoria", "programa" e "prática". As primeiras tiragens foram de 5.000 exemplares, caindo para 3.000 e depois para 2.000, quando a estatal Gosizdat retirou o patrocínio. Sua sucessora, Novyi Lef [Nova Lef] começou a ser impressa em janeiro de 1927 e cessou definitivamente em dezembro de 1928, com vinte e duas edições, incluindo uma dupla, com tiragens variando entre 2.400 e 3.500 exemplares. Rodchenko desenhou todas as capas de Novyi Lef, e contribuiu com artigos $\mathrm{e}$ conteúdo. Ver Victor Margolin (1998, p. 105) e Magdalena Dabrowski e Leah Dickerman (2002, p. 304-307).

25. Poeta futurista (18931930). Parceiro de Rodchenko em diversos grupos, publicações e empreendimentos de 1922 até sua morte.

26. Ver Leah Dickerman (1997, p. 8) e Leah Dickerman. In: Dabrowski, Dickerman (1999, p. 64). deste modo a política deveria interferir para que a arte não se desviasse de tal propósito ou passasse qualquer mensagem errada aos seus receptores. De maneira mais explícita, Lênin chegou a afirmar que "a arte é uma arma na guerra de classes para ser usada somente sob a guia cuidadosa, mas firme, do Partido Comunista"23.

Também de conołação bélica, nada casual, foi a denominação do LEF - sigla para Frente Esquerda das Artes ${ }^{24}$ - grupo de vanguarda fundado pelo poeta Vladimir Maiakovski25. Segundo Leah Dickerman, o grupo teria construído uma teoria de criação artística unindo o marxismo ao modelo semiótico do formalismo russo. Essa teoria afirmava dois pontos principais: que forma e técnica seriam ambas ideológicas, e portanto uma arte transformadora deveria buscar novas formas e novas técnicas de sua feitura; e que a mudança interior de um indivíduo ocorreria por meio da práxis, e assim uma arte transformadora deveria não só ser criada por meio de elaboração mental, mas deveria gerar no seu espectador igualmente uma elaboração mental ${ }^{26}$.

Os artistas e intelectuais reunidos no grupo LEF - Maiakovski, o construtivista; Aleksandr Rodchenko o crítico; Ossip Brik, o poeta e dramaturgo; Sergei Tretiakov, o teórico formalista; Victor Chclóvski, o teórico marxista; Boris Arvatov e o cineasta Dziga Vertov, entre outros - travaram uma batalha na tentativa de transformar os indivíduos por meio da arte, para que eles se tornassem mais aptos a viver em um mundo moderno e socialista. No que se aproxima de um programa do grupo, publicado em 1923, o LEF afirma que se muniu da arte para declarar guerra ao gosto, comparada à guerra que os partidos revolucionários declararam ao modo de vida - nos dois casos, referindo-se ao julgamento estético tradicional, identificado por eles com a cultura burguesa ${ }^{27}$. Da mesma forma que outros grupos artísticos da primeira década do século vinte, os artistas da vanguarda russa se levantaram contra os princípios estéticos ligados historicamente à arte, como por exemplo a perspectiva albertiana, e algumas vezes até contra os próprios meios artísticos tradicionais, como a pintura de cavalete e a escultura. Representada pelas academias de arte, essa arte tradicional era patrocinada e consumida por parte da burguesia, tornando a revolta dos grupos de arte moderna contra os valores da arte tradicional também uma postura política de oposição a essa classe social.

Conclamando os artistas de esquerda, o texto do LEF segue defendendo a construção de um futuro - em oposição aos hábitos do passado, não só na arte, que deveriam ser deixados para trás - por meio da construção estética, do fazer artístico do grupo, inovador e exemplar, que era pautado pelo ideário socialista. "Trabalhando para fortalecer as conquistas da Revolução de Outubro pelo fortalecimento da arte de esquerda, a Lef vai agitar a arte com as ideias da comuna e abrir para a arte a estrada do amanha ${ }^{\prime \prime 28}$ : para eles, a arte e a política estariam tão unidas, que ao defender o fortalecimento da arte de esquerda, segundo o texto, os artistas estariam fortalecendo as conquistas da própria Revolução. A ação artística do grupo era para eles, portanto, uma ação também política. Este agir ou fazer artístico significava uma profunda interação com o espectador, ou receptor, desta arte. 
Nos primeiros anos que se seguiram à Revolução de Outubro, tanto o Partido Comunista como grande parte dos intelectuais de esquerda acreditavam que o Estado socialista estava concretizado, mas que os indivíduos ainda mantinham costumes pré-revolucionários, calcados no passado dominado pela cultura burguesa, que deveriam ser modificados. A noção de byt-costume, modo de vida cotidiano - ganhou importância e atenção: o modo de vida da população russa deveria ser transformado em um modo de vida condizente com a ideologia materialista $^{29}$. $\bigcirc$ Partido teria papel regulador desta transformação, mas grupos e instituições artísticas, como o LEF, adiantaram-se e muitas vezes tomaram para si a tarefa de transformar não só o antigo byt, como também o antigo homem de ideias aburguesadas no Novo Homem Soviético ${ }^{30}$. Ainda na primeira edição da revista Lef, S. Tretiakov corroborou a necessidade de tal tarefa: "O que guiou o Futurismo desde os dias de sua infância não foi a criação de novas pinturas, versos e prosas, mas a produção de um novo ser humano através da arte, que é uma das ferramentas de tal produção"31.

Rodchenko uniu-se ao LEF ainda no momento da gestação do grupo, contribuindo com sua arte e teoria construtivista já na primeira edição da revista por eles publicada. Suas fotomontagens, fotografias e artigos estiveram presentes em todas as edições de Lef, e depois de Novyi Lef. Além de ser o responsável pela primeira capa, com uma fotomontagem de sua autoria - e por praticamente todas as subsequentes -, nesta primeira edição de 1923 constava um artigo de Ossip Brik (1888-1945), intitulado "À produção!" (V proizvodstvo!), defendendo o comprometimento de Rodchenko com os ideais do LEF; no interior do artigo havia uma inserção de página dupla trazendo exemplos do "trabalho do construtivista Rodchenko". Esta mesma edição trazia também o anúncio de uma exposição construtivista na qual o artista mostrava algumas obras, enumerando-as e afirmando que, coadunando com os ideais do LEF, "Os Construtivistas romperam completamente com a atividade experimental, para ser mais exato abstrata, e passaram para o trabalho real do plano de um 'trabalho [labor] artístico socialmenteinterpretado'" 32. A presença do artista não foi menor nas edições seguintes da revista e de sua sucessora, tendo seu trabalho evoluído juntamente com a evolução teórica e institucional do grupo Lef 33 .

Já no programa do Primeiro Grupo de Trabalho Construtivista, que Rodchenko assinou juntamente com Varvara Stepanova e Alexei Gan em 1921, dois anos antes do programa do LEF, estava explícita uma forte ideia de mútua implicação entre arte e política. $\bigcirc$ fazer artístico dos construtivistas foi amplamente teorizado ${ }^{34}$, no sentido de propor uma união da forma estética com o conteúdo ideológico, expressando ideias comunistas no suporte artístico e assim materializando-as. Em fins de 1921, porém, Rodchenko já havia se desvencilhado permanentemente da arte tradicional, como por exemplo a pintura de cavalete. Tal atitude torna a presença marcante da ideia de estética no programa do LEF, de 1923, plena de significados. A política e a arte eram concebidas como conectadas de tal forma, que foi possível ao grupo afirmar que a "Lef vai lutar pela construção
27. O texto começa declarando: "Os partidos revolucionários travaram guerra contra um estilo de vida, a arte se levantou para travar guerra contra o gosto". Ana Lawton e Hebert Eagle (2004, p. 191195). Publicado com o título What Does Lef Fight For? na revista Lef $n$. 1 , 1923, na seção Programa. Grifos no original.

28. Cf. Ana Lawton e Hebert Eagle (2004, p. 195). Grifos no original.

29. Sobre o papel da noção de byt dentro da Rússia pós-revolucionária, ver Christina Kiaer (2005, cap. 2); John Bowlt e Olga Matich (1996). Ver, em especial Remaking the Bed: Utopia in Daily life, de Olga Matich (1996, p. 59-79).

30. Novo Homem Soviético é uma terminologia surgida no período pósrevolucionário que se refere ao homem exemplar para a construção do novo mundo socialista, na visão do Partido Comunista e de seus seguidores. Houve muitos estudos científicos com o intuito de fomentar a formação deste homem por meio da educação das crianças, como por exemplo os estudos psicológicos de Vigotski e de Makarenko. O termo ganhou mais força no período stalinista, e havia grande propaganda em torno deste homem exemplar. Ver Fernando Nadra (1983, p. 147-148).

31. Cf. Ana Lawton e Hebert Eagle (2004, p. 208).

32. Cf. Leah Dickerman (1997, p. 3-4).

33. Ibidem (p. 5). 34. Ibidem (p. 8). 
35. Cf. John E. Bowlt e Olga Matich (1996, p. 9-10).

36. Ver Robert Hugues (1995, p. 95).

37. Ver Alexander Lavrentier (2005, p. 31-670); Magdalena Dabrowski. In: Peter Galassi; Magdalena Dabrowski e Leah Dickerman (1999, p. 20). estética da vida". Neste contexto, tal construção dá a entender que para os artistas envolvidos a política pulsava tão forte dentro da arte, que uma e outra eram unidas em um mesmo éthos ${ }^{35}$.

Foi imerso nesse debate, na busca de um meio artístico que melhor se adequasse às mudanças sociais e políticas que a Rússia passava desde 1917, que Rodchenko começou a fazer fotografias, em 1924. A opção pela câmera teve seus motivos, que não se limitaram apenas ao âmbito estético. Para ele, as características de imagem técnica da fotografia - sua instantaneidade, seu caráter de índice do real, a facilidade de uso e o baixo custo, que tornavam a fotografia potencialmente uma arte democrática, e o potencial de infinita reprodução mecânica-coadunavam perfeitamente com os ideais revolucionários ${ }^{36}$.

A busca da síntese entre forma e ideologia, declarada ainda em 1921, pareceu-the melhor frutificar no meio fotográfico. Sua experimentação e atuação foram pautadas pela necessidade de construir uma cultura política que atingisse as massas da população, como queria Lênin, e que fosse em consonância com os ideais do LEF, unindo um meio claramente técnico, com o qual ele acabava de entrar em contato - a máquina fotográfica - a uma forma altamente revolucionária - uma linguagem para esse meio que ainda estava por ser criada. $\bigcirc$ declarado engajamento do artista com os ideais que estavam em jogo neste momento o aproximou da frente de batalha, e a arma que usou então, aos moldes do que afirmara Lênin, foi sua arte. Como se verá a seguir, sua artilharia de predileção variou desde a régua e o compasso até a câmera.

Rodchenko e os primeiros momentos da vanguarda russa

Aleksandr Mikhailovich Rodchenko nasceu em 23 de novembro de 1891 em São Petersburgo. Em 1909 ele entrou na Escola de Belas Artes de Kazan, cidade para onde a família havia se mudado, como ouvinte, pois não possuía segundo grau. Em 1914, ele obteve um certificado atestando a conclusão do curso e conheceu Varvara Stepanova, que se tornou sua companheira até a morte do artista, 1956, em Moscou. Durante o período em que estudou em Kazan, seus trabalhos traziam traços simbolistas e cubistas. Ainda em 1914, porém, Rodchenko assistiu a uma palestra dos futuristas David Burliuk, Viktor Kamenenski e Vladimir Maiakovski, na qual procuravam engajar jovens artistas nos debates que estavam promovendo sobre a relação entre arte europeia, principalmente o cubismo, e a arte russa. Rodchenko saiu da palestra encantado pelo futurismo, e suas pinturas e desenhos dali em diante espelharam esta mudança ${ }^{37}$.

A denominação de "futurista" que então era dada a este grupo de artistas e intelectuais, no entanto, não faz referência direta, tampouco os inclui, ao movimento Futurista italiano. Com poucas ideias similares aos colegas italianos, e sem formar uma escola artística única e coesa, o futurismo russo correspondeu efetivamente a uma denominação genérica para a arte e literatura 
de esquerda que se desenvolveu na Rússia a partir da primeira década do século vinte ${ }^{38}$.

país viveu nestes anos uma intensa acolhida da arte moderna europeia, bem como uma estreita ligação com os grupos artísticos mais inovadores, que se dissolveu apenas em 1914, com o início da Primeira Guerra Mundial. A presença de Wasily Kandinski, além de outros russos, como nomes importantes do grupo Der Blave Reiter; a recepção que os Nabis possuíam lá, em especial junto aos simbolistas, tendo Denis visitado diversas vezes São Petersburgo; e a formação das importantíssimas coleções de Morosov e Shchukin que, por motivo de duas aquisições deste último, em 1911 , levou Matisse a viajar pessoalmente a Moscou para entregar Música e Dança e instalá-las na mansão da família, dão uma ideia do cosmopolitismo artístico que vigorou na Rússia. Shchukin foi o responsável pela introdução dos pós-impressionistas no país, e sua coleção serviu de inspiração para a geração de jovens artistas que emergia, como Kazimir Malevich ${ }^{39}$.

Neste ambiente artístico, movido pela troca internacional de ideias a respeito da arte moderna, a geração de futuristas russos foi formada. Os primeiros nomes importantes foram os pintores Natalia Goncharova e Mikhail Larionov. Em seguida uniram-se a eles os irmãos David e Vladimir Burliuk, Vladimir Maiakovski, colega de faculdade de David e Alexandra Exter, entre outros. Eles organizavam exposições, faziam filmagens amadoras de suas histórias, atuavam em espécies de precursores dos happenings, vestiam-se de forma chamativa, não usual, por vezes com os rostos pintados, e organizavam e proferiam palestras, como a que Rodchenko assistiu em 1914.

Kandinski também se aproximou do grupo, mas suas ligações com o Simbolismo e com o modo de pensar a arte que trazia da geração anterior fez com que não fosse tão bem recebido pelos outros membros, mais novos que ele. Malevich juntou-se a eles, trazendo muitas referências, no início, de Goncharova e Cèzanne. Desligou-se, porém, em 1912, quando ainda gestava o que viria a ser o seu Suprematismo 40 . Vladimir Tatlin também fez parte do grupo, motivado, do mesmo modo, por Goncharova e Larionov, tornando-se atento às pinturas de ícones religiosos, tradicionais da cultura russa desde o período medieval, que a artista havia the apresentado. No entanto, em 1913, Tatlin partiu para Berlin e Paris. Na cidade francesa bateu à porta de Picasso, de quem conhecia as obras da coleção de Shchukin, e pôde ver as construções cubistas que ele vinha desenvolvendo. Quando voltou para Moscou, Tatlin iniciou a pesquisa com suas pinturas de relevo e baixo-relevo. Os rumos do grupo futurista mudaram, porém, em 1915, quando Larionov e Goncharova foram viver no exterior. $\bigcirc$ Futurismo russo perdeu um pouco de sua força, e Malevich tomou, no lugar destes, a posição de líder da vanguarda artística russa.

cenário de cosmopolitismo, de centro de encontro e troca entre artistas da Europa, mudou na Rússia com o início da Primeira Guerra Mundial. A partir de 1914 - e até 1921, quando os bloqueios do período revolucionário caíram - a Rússia viveu um isolamento forçado em relação ao resto do mundo. A guerra
38. Vahan D. Barooshian afirma que a maior contribuição tomada do Futurismo italiano pelos russos foi uma certa base teórica, emprestando alguns slogans para seus manifestos. Ver Vahan D. Barooshian (1974, p. 146).

39. Camilla Gray comenta que tais coleções, c u i d a d o s a m e $\mathrm{n}$ e selecionadas pelos dois colecionadores, teriam servido para os jovens artistas russos nas décadas de 1900-1910 como um "curso intensivo sobre a pintura revolucionaria francesa dos últimos quarenta anos". Ver Camilla Gray (2000, p. 70).

\footnotetext{
40. Foram citados por Malevich como membros do grupo suprematista, em sua declaração de 1915, From Cubism and Futurism to Suprematism: The New Painterly Realism, além dele próprio, também I. Puni, M. Menkov, I Klyun, K. Boguslavskaya e Rozanova. Ver John E. Bowlt (1988, p. 135).
} 
41. Camilla Gray (2000, p. 212-213). obrigou muitos artistas russos que moravam na Europa a voltarem para seu país. Um exemplo é Kandinski, que estava em Munique. Deste modo, em plena efervescência, a vanguarda russa, com toda a sua bagagem europeia, desenvolveuse a partir de 1914 de forma relativamente autônoma. Moscou e São Petersburgo, depois renomeada Petrogrado, tornaram-se centros de atividade artística incansável.

Em 1914, Rodchenko assistiu a palestra futurista, e já no ano seguinte, em 1915, mudou-se para Moscou, onde entrou em contato com os membros do grupo e com outros artistas que juntos representavam o coração da vanguarda russa. Em 1916, foi convidado a participar da exposição A Loja, em Moscou, onde conheceu pessoalmente Tatlin e Malevich, que também expunham. Rodchenko mostrou na ocasião alguns resultados de pesquisas pictóricas que vinha conduzindo em desenhos não objetivos - que não se encaixam na categoria de abstratos e que não trazem relação com objeto algum a ser representado - utilizando-se de régua e compasso. Já então ele experimentava com a serialismo e com a mediação mecânica entre a mão e a obra. No entanto, o encontro com a produção artística desses dois expoentes da vanguarda russa repercutiu por muito tempo em sua obra.

Camilla Gray afirma que esse contato com Malevich e Tatlin teria causado significativo impacto na obra de Rodchenko. De Malevich, ele teria absorvido o uso do eixo dinâmico presente em toda a sua obra, e o uso de formas geométricas puras; de Tatlin teria vindo o interesse em materiais e texturas, e, "de uma combinação destas duas influências Rodchenko desenvolveu o sistema de design construtivista do qual ele foi pioneiro"4l.

Tatlin e Malevich, desde a volta do primeiro para a Rússia até o fim de sua vida, alimentaram uma grande rivalidade que, por vezes, levou-os ao confronto físico. Nos primeiros tempos em Moscou, Rodchenko transitou entre o contato mais próximo com um e outro. Com o tempo, Rodchenko permaneceu mais próximo de Tatlin, que o aconselhou a se afastar de Malevich - apesar de nenhum dos dois artistas terem perdido de vista o trabalho que Malevich desenvolveu.

Tanto Malevich quanto Tatlin haviam deixado de lado a representação realista em favor de uma representação baseada em formas geométricas, porém de modos diferentes. Malevich buscou este modo de representação por meio de obras bidimensionais, enquanto que Tatlin buscou-o além do espaço pictórico. Sua arte preocupou-se com a materialidade tanto dos objetos quanto da obra de arte. $\bigcirc$ aparato que engendra essa obra era considerado como presença do real dentro dela.

Rodchenko, Malevich, Tatlin

Em fevereiro de 1917, porém, houve a revolução burguesa, que derrubou o Czar e buscou instituir a democracia. Nesta ocasião, quase a totalidade da comunidade artística de São Petersburgo se reuniu para criar um conselho gestor dos assuntos artísticos com o novo governo. A preocupação dos artistas a partir desta primeira turbulência política - que se manteve forte até muitos meses depois 
da segunda revolução, a de Outubro - era, segundo Hubertus Gassner, assegurar a autonomia da arte frente ao poder político ${ }^{42}$. No entanto, a União de Trabalhadores da Arte, como o conselho gestor se chamou, existiu apenas de abril a maio de 1917, pois seus debates acabaram levando a um racha. Embora os artistas e intelectuais lá reunidos estivessem todos engajados na realização de uma renovação cultural, houve uma separação entre os de tendências mais à esquerda e os mais à direita, estes a grande maioria.

Ligados à Academia Imperial de Artes, a mais importante instituição artística até 1916, e ao subsequente grupo Mundo da Arte, estes últimos eram defensores de uma estética realista e preocupavam-se em manter seu antigo status de pilares da cultura russa. Eles defendiam a completa separação entre os âmbitos da arte e da política. Por outro lado, dentre os artistas e teóricos mais à esquerda, que não possuíam um status a preservar e defendiam uma ruptura mais radical com a estética anterior, os futuristas eram os mais envolvidos, e dos poucos que defendiam o comprometimento social e o engajamento político da arte. Esta cisão entre direita e esquerda artística manteve-se mais tarde, como se pode perceber na denominação do grupo LEF - Frente Esquerda das Artes -, fundado em 1923.

Ainda segundo Gassner, nos meses que separaram fevereiro de outubro de 1917, as massas da população russa foram se tornando cada vez mais hostis, chegando a igualar como sinônimos as categorias de intelectual, artista e burguês. Deste modo, após a revolução bolchevique de outubro, os membros da ala direita mantiveram-se afastados do novo regime, ainda com mais ressalvas do que possuíam contra o anterior. Por outro lado, o governo bolchevique esforçou-se desde os meses iniciais em criar instituições estatais que englobassem os grupos artísticos, o que os artistas temiam se tornar um controle estatal em cima da criação estética.

Tal ressalva também fez parte das preocupações dos artistas de esquerda, que de resto se mostraram mais receptivos do que os de direita ao novo regime. Defendendo a liberdade artística, muitos dos artistas foram, nesses primeiros instantes, partidários do movimento anarquista russo, que obtinha certo vulto até meados de 1918, passando a ser perseguido e deixando de existir definitivamente em 1920. Tatlin, Rodchenko, Maiakovski e Malevich foram alguns dos artistas de esquerda que simpatizaram ou colaboraram em diferentes níveis com o anarquismo nos primeiros meses da revolução.

Isto não os impediu de abraçar totalmente, meses depois, a causa bolchevique. Assim, quando a construção do governo socialista russo foi assegurada e o Estado soviético começou a se consolidar, Tatlin e Malevich afirmaram que haviam antecipado os acontecimentos de outubro em sua arte, legitimando-os e incorporando-os à agenda da vanguarda artística. Tatlin afirmou: "Os eventos de 1917 no campo social já haviam sido provocados pela nossa arte em 1914 quando 'material, volume e construção' foram assentados como suas 'bases'"43. E Malevich: "Cubismo e Futurismo foram formas revolucionárias
42. Ver Hubertus Gassner (1992, p. 299-302).

43. Cf. Camilla Gray (2000, p. 219), tradução da autora. 
44. Ibidem, tradução da autora.

45. Segundo Gray, entre 1918 e 1921, quando o grupo foi desfeito, 36 museus foram fundados pela Rússia e havia o projeto para mais 26. A autora comenta que a participação de Rodchenko na seção de aquisições de obras de arte não foi inteiramente imparcial, tendendo para as obras de vanguarda e para os artistas com os quais possuía mais afinidade. Ver Camilla Gray (2000 p. 230).

46. Ver Lênin, V. I. (1975, p. 225-227). na arte que prenunciaram a revolução da vida política e econômica de 1917"44. Ambos atrelaram o desenrolar dos eventos políticos aos dos estéticos.

Após a Revolução de Outubro de 1917 a arte passou a ser gerida pelo Estado. Lênin criou quase que imediatamente o Narcompros - Comissariado do Povo para a llustração -, instituição que ficou a cargo de Anatoli Lunacharski (1875-1933), e que gerenciava a Izo - Seção de Artes Visuais - e o INKhUK Instituto de Cultura Artística. Lunacharski era crítico de arte que, em decorrência de sua associação com os bolcheviques, havia passado alguns anos em exílio na Europa. Com o novo cargo, nomeou para auxiliá-lo um grupo de artistas seus conhecidos. Foram chamados tanto artistas com tendências de esquerda quanto de direita, tendo, porém, os primeiros mais influência e poder. Fizeram parte deste grupo Wassily Kandinski, Natan Altman, Nikolai Punin, Ossip Brik e Olga Rozanova.

Como alguns artistas, na maioria os da direita, ainda se mostravam reticentes, uma das formas de trazê-los para dentro do comissariado foi a adoção de uma política preservacionista. Durante a revolução e, em especial, quando da tomada do Palácio de Inverno, algumas obras de arte foram vandalizadas ou destruídas, o que assustou muitos dos artistas da academia russa. Preocupando-se com a preservação da arte do regime anterior, parte do prestígio e do status dos artistas deste regime era resguardada, e assim membros do Mundo das Artes aceitaram alguns dos altos cargos que lhes foram oferecidos por Lunacharski.

Dentro deste espírito preservacionista, uma das primeiras atitudes tomadas pelo grupo de artistas que fazia parte, agora, da instituição que observava as artes foi formar o Departamento de Museu e Fundo de Aquisição. Este departamento foi responsável por montar museus pela Rússia a partir de aquisições de obras de todas as escolas artísticas do país. Rodchenko foi contratado como diretor da seção de aquisições desta instituição em $1918^{45}$. 0 artista também exerceu outras funções em instituições estatais: ainda em 1917, ele ajudou a fundar o Sindicato dos Artistas-Pintores Profissionais, o Profsoiuz, e em 1918 passou a ser membro do Conselho dessa instituição. Em 1918 começou também a lecionar teoria da pintura no braço de Moscou da Proletkult, Associação de Cultura Proletária, bem como a produzir cartazes para o Plano de Propaganda Monumental ${ }^{46}$, lançado por Lênin em abril daquele ano.

De 1917 a 1921, os artistas da vanguarda russa viveram um período de intensa criação e de intensos debates. $\bigcirc$ mundo havia se transformado, e as instituições tradicionais, que antes viam as inovações que estes jovens artistas propunham com descrédito, estavam agora sendo substituídas por novas instituições a cargo destes mesmos jovens. $\bigcirc$ sentimento de estar escrevendo a história, de estar criando um mundo novo, aparece com clareza nas memórias de Artur Lur'e (1892-1966), compositor russo cuja repulsa ao academicismo musical o levou a buscar uma escala de doze tons já em 1914, bem como a colocar-se ao lado dos bolcheviques em 1917: 
Assim como meus amigos - jovens artistas e poetas da vanguarda - eu acreditei na Revolução de Outubro e imediatamente me alinhei a ela. Graças ao apoio mostrado por nós à Revolução de Outubro, todos nós, jovens artistas - inovadores e experimentalistas fomos levados a sério. Em princípio visionários pueris falaram sobre serem capazes de realizarem sonhos (...), mas em geral nem política nem poder se intrometeram realmente na arte pura. Nos deram liberdade total em nosso campo para fazermos tudo o que queríamos; foi a primeira vez na história que houve uma tal oportunidade. ${ }^{47}$

As criações artísticas, que neste momento eram desenvolvidas com relativa liberdade, iam se somando e se sobrepondo. Cada artista, a seu modo, procurava uma forma de contribuir para a construção do que seria um novo mundo por meio da arte, bem como uma forma de torná-la necessária e coerente neste novo cenário. Assim como para toda a vanguarda, para Rodchenko foi um momento muito produtivo. Percebe-se na sua produção desses anos ao mesmo tempo um diálogo estreito e uma tentativa de diferenciação com o trabalho de Malevich, Tatlin e Kandinski.

As principais obras de Rodchenko de 1917 são desenhos de objetos de uso, especialmente de cúpulas e abajures para o Café Pittoresque de Moscou, primeiro trabalho em desenho aplicado à produção que ele realizou, a convite de Tatlin. De 1918, no entanto, há muitas pinturas em tela, onde o artista dá a ver a pesquisa estética que estava desenvolvendo. São desta data os primeiros trabalhos em série, um modo de fazer artístico que depois ganharia força no período em que se dedicou à fotografia. Exemplos das pinturas em série são as que compõe Concentração na cor (1918-20), na qual se vê preocupação com a forma geométrica, as intersecções entre círculos cheios e apenas contornados - que remete aos seus desenhos de 1915. Há, porém a presença da cor, com o uso preponderante das cores primárias, o amarelo, o azul e o vermelho, além do preto. Já em Preto sobre Preto, de 1918, o uso de cores é novamente limitado, com a predominância do preto e do cinza. Os motivos são em sua maioria novamente circulares, e o branco é usado para conferir movimento à pintura, dando a sensação de uma espiral. Apresentam também o deslocamento em diagonal, muito presente nas obras tanto de Malevich (Figura 1) quanto de Tatlin, e também nas fotografias que Rodchenko veio a fazer na década seguinte. Esta série demonstra que o artista estava entrando cada vez mais na sua busca pelo elementar e pela economia do pictórico - representada não só por meio da ausência de cor, mas também pelo encaixe das formas, que fornece uma economia de espaço - mas que não diminue a expressividade da pintura. Levando-se em conta que Malevich havia inaugurado o Suprematismo em 1915 com o seu Quadrado negro, e em 1918 havia acabado de exibir Branco sobre branco, sua tela mais ousada até então, a série de Rodchenko parece estar dialogando diretamente com as duas obras de Malevich. Assim, enquanto este propôs um novo realismo por meio de formas geométricas, o não objetivo absoluto, a série de Rodchenko parece intentar ir além, ou seja, a partir das
47. Cf. Christina Lodder (1987, p. 48), tradução da autora. 
48. A pintura suprematista de Malevich foi exposta pela primeira vez na mostra $0: 10$ em Moscou em 1915, e as de Rodchenko na Décima Mostra Estatal: Criação NãoObjetiva e Suprematismo organizada pela Izo Narcompros em Moscou em 1919. Sobre a relação entre a pintura de Malevich e a de Rodchenko, ver Magdalena Dabrowski. In: Peter Galassi; Magdalena Dabrowski e Leah Dickerman (1999, p. 28-31) e Camilla Gray (2000, p. 240). mesmas características elementares das telas de Malevich, negar o seu caráter de absoluto. Rodchenko o fez conferindo textura à superfície da tela. Essa é uma característica fundamental para ele e seus pares - a chamada factura, o tratamento da superfície da tela, a substância material que, ao mesmo tempo reveste sua superfície e faz parte do próprio teor pictórico do quadro. As telas de Malevich, no entanto, são lisas, sem textura ou elementos ressaltados.

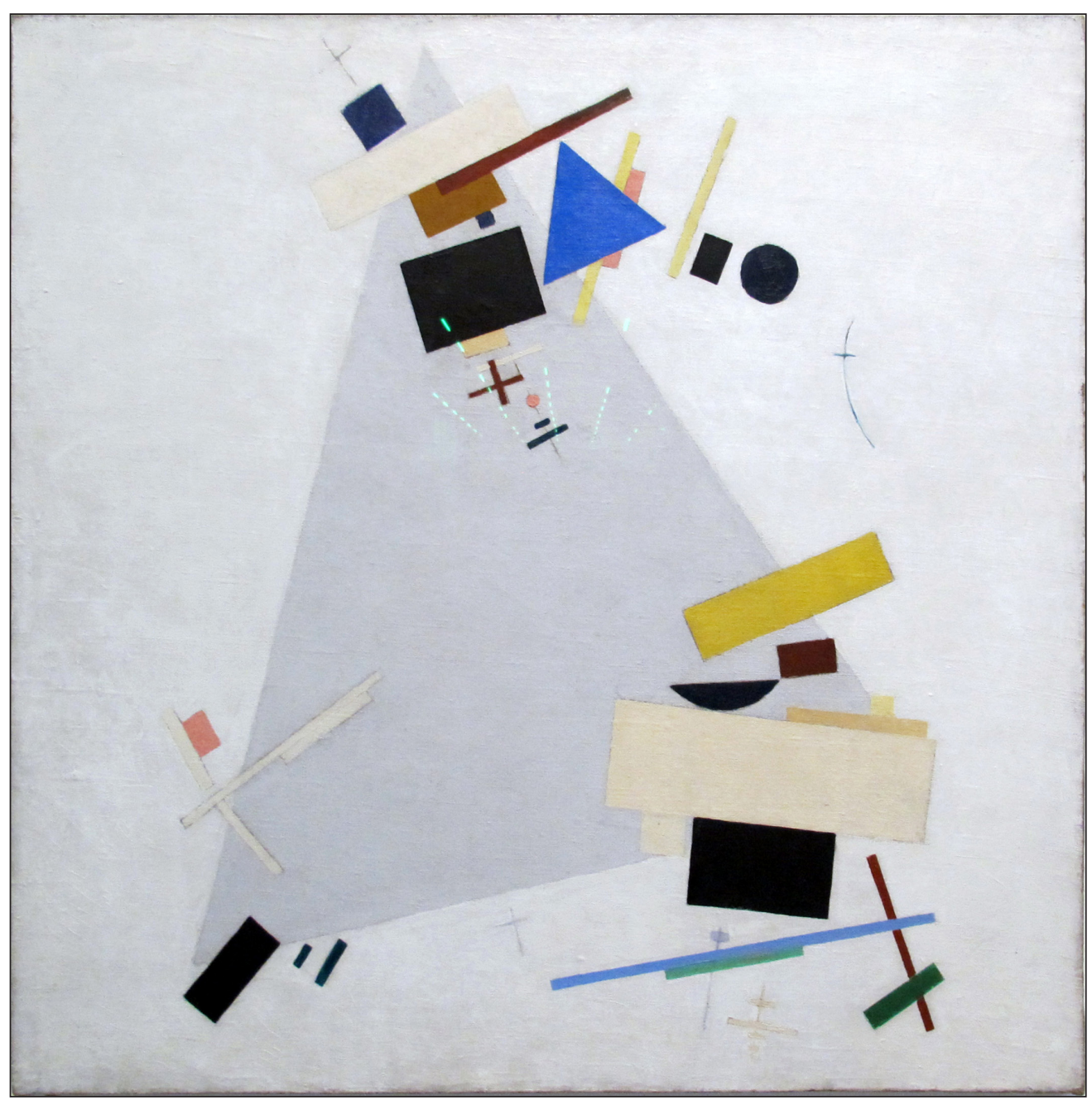

Figura 1 - Malevich. Suprematismo dinâmico, 1916. Óleo S/ Tela, 60x73, Tate Gallery, Londres. Disponível em: <https://commons.wikimedia.org/wiki/File:Kasimir_malevich,_suprematismo_ dinamico,_1915_o_1916.JPG? uselang=pt-br>.

A série de Rodchenko foi muito bem recebida pela crítica e pelos artistas da época ${ }^{48}$. Porém, ela demonstra um caráter de competição entre os artistas caráter também demonstrado nas palavras que Varvara Stepanova, esposa de Rodchenko, escreveu em seu diário quando a série foi exposta: 
Finalmente nossa exposição de "não-objetivistas e Suprematistas" está quase pronta (...). Malevich expôs 5 quadros brancos, Anti [i.e. Rodchenko] - pretos. É claro, Malevich não descobriu nada. Ele pintou um quadrado branco em um fundo branco, não é nem pintado, é somente colorido. Obviamente Anti ganha dele em pintura e em factura e mesmo se ele ainda não tivesse à frente de Malevich, ele se tornou uma figura de importância com quem se deve contar. (...) onde seus trabalhos pretos estão ganhando é no fato de que eles não têm cor, eles são fortes por meio da pintura, eles não são enevoados por nenhum elemento externo, nem mesmo cor. É óbvio que seus quadros pretos são na verdade a fúria da temporada. Com eles, ele mostrou que a factura é ... o que o próximo passo em pintura depois do suprematismo é ... o que a realização profissional é ... um modelo para um novo tipo de pintura de cavalete. ${ }^{49}$

Vê-se pelas obras que produziu a partir de 1917-1918, e pelo que publicou em catálogos de exposição e em escritos teóricos, que a preocupação de Rodchenko era a de constantemente explicitar as suas filiações e o seu ideário político, ao produzir obras que experimentavam esteticamente com o intuito de ser consideradas cada vez mais revolucionárias e transgressoras da arte tradicional. É, neste sentido, significativo o fato do artista, juntamente com Aleksandr Drevin, Liubov Popova, Varvara Stepanova, Aleksandr Vesnin e Nadeza Udaltsova, ter fundado, em janeiro de 1919, a Asskranov, ou Associação de Inovadores Radicais, que se declarava abertamente contra o Suprematismo de Malevich.

Afastando-se ideologicamente de Malevich, Rodchenko também vinha discordando de Tatlin quando, em 1918, começou a criar esculturas abstratas. Nesse ano, ele fez seis construções espaciais ${ }^{50}$, que não sobreviveram a não ser em poucas fotografias e desenhos nos cadernos do artista. Em seus escritos, fez referência aos relevos e baixos-relevos de Tatlin. Não só os relevos de Tatlin, mas também sua obra mais conhecida, o Monumento à Terceira Internacional (Figura 2), dialogam com criações de Rodchenko. Como em Malevich, há em Tatlin a presença dominante das formas geométricas. As linhas, que Rodchenko vinha derivando de sua desconstrução progressiva do pictórico, como na Construção n 92, aparecem tanto no monumento de Tatlin quanto, de forma mais pronunciada, em seu Relevo de 191415. Do mesmo modo, a construção circular em espiral daquela, com seu eixo deslocado diagonalmente, remete aos círculos concêntricos da Construção espacial $n^{\circ} 12$ (Figura 3), alguns meses anterior. Durante a Terceira exposição do OBMOKhU, em que a construção foi exibida pela primeira vez, relata-se que Rodchenko lançava feixes de luz que a trespassavam e projetavam sombras intricadas nas paredes. Semelhante efeito poderia ser antecipado também para o monumento de Tatlin, ao ser iluminado pelo sol, caso tivesse sido efetivamente construído. Ressaltando a própria autoria destas construções, que se adiantou à de Tatlin ao se destacar da parede e ganhar a materialidade de objetos que não objetos de arte, Rodchenko afirmou que possuíam maior inovação e radicalismo formal pois, ao contrário dos relevos de Tatlin, suas peças foram feitas para serem olhadas por todos os lados. Ele reforçou as diferenças entre estas construções e os relevos em um escrito de 1922. Segundo ele, "Em primeiro lugar eles significaram o abandono da pintura para o movimento em direção ao espaço real. Tatlin ainda não tinha se decidido a dar este
49. Cf. Magdalena Dabrowski. In: Peter Galassi; Magdalena Dabrowski e Leah Dickerman (1999, p. 28-29), tradução da autora.

50. Duas delas também exibidas na Décima Mostra Estatal. Ver Magdalena Dabrowski. In: Peter Galassi; Magdalena Dabrowski e Leah Dickerman (1999, p. 32). 
51. Cf. Aleksandr Rodchenko. In: Selin O. Khan-Magomedov (1986, p. 38 , nota 2), tradução da autora. Dabrowski completa, afirmando que Tatlin apenas tomaria essa direção um ano depois, com seu Monumento à Terceira Internacional, uma "construção espacial à la Rodchenko". Ver Peter Galassi; Magdalena Dabrowski e Leah Dickerman (1999, p. 33), tradução da autora. passo e tinha construído contra-relevos que ainda estavam presos à parede e como pinturas não podiam ser olhados por todos os lados"5l.

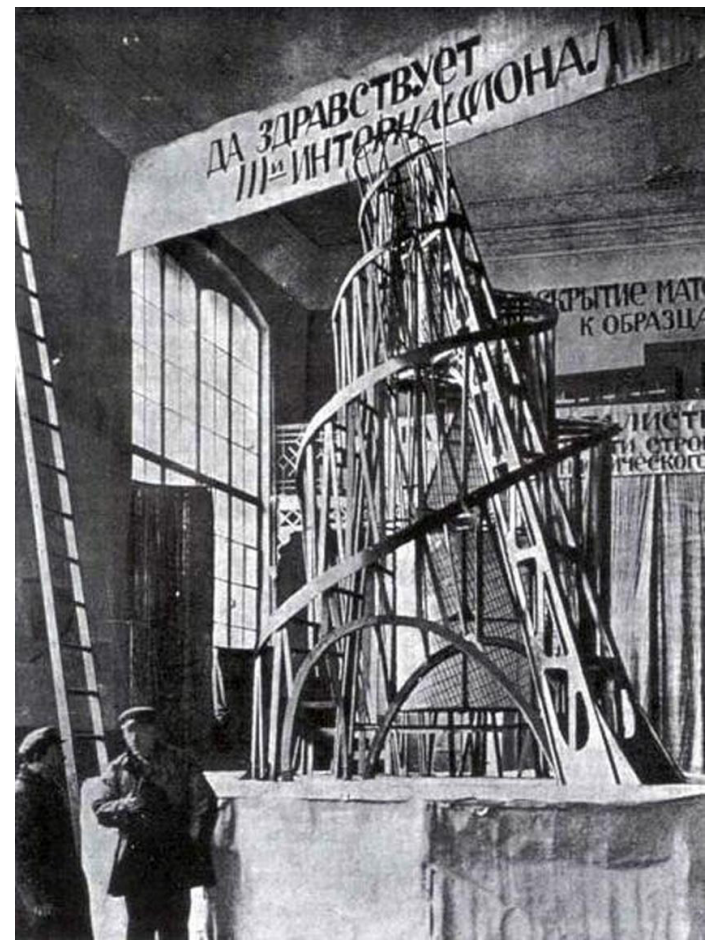

Figura 2 - Autor desconhecido. Modelo do Monumento à Terceira Internacional, 1919. Fotografia. Disponível em: <http://commons.wikimedia.org/wiki/File:Tatlin\%27s_Tower_maket_1919_year.jpg>.

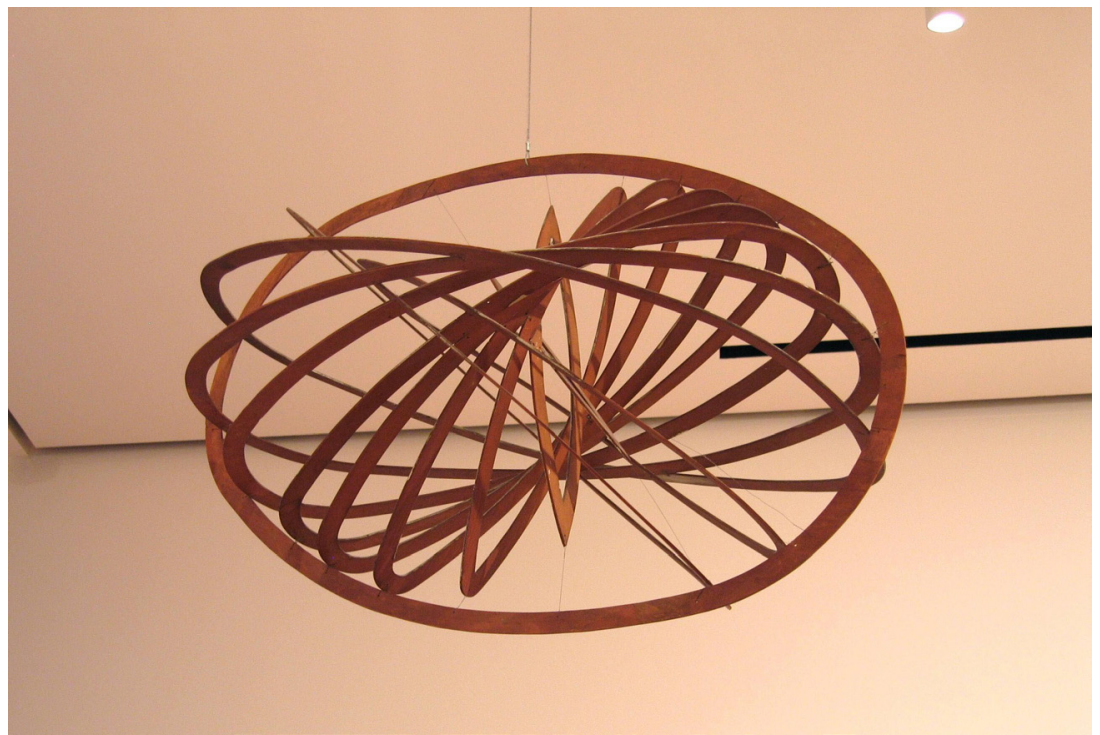

Figura 3 - Aleksandr Rodchenko. Construção espacial n. 12, 1920. Madeira compensada pintada e arame. Disponível em: <http://commons.wikimedia.org/wiki/File:Spatial_construction_n 12. JPG? uselang=pt-br>. 
movimento em direção ao "espaço real" defendido pelo artista, com a busca da materialidade da tela, e sua consequente tridimensionalidade, por meio da factura, levava-o para fora da parede onde se confina a obra de arte. Ou seja, ele buscava a presença do material, do concreto, que o afastasse mais da ideia de arte e que o aproximasse de uma construção de engenharia. Que não se prendesse a uma representação "ilusória", mas que fosse engendrada por aparato ou técnica correlata ao engendramento de um país socialista, e que já tinha chamado a sua atenção para a factura da pintura em tela, e foi assim também fundamental na passagem para a fotomontagem, e em seguida para a opção efetiva pelo fotografar.

Em outubro de 1920, na Décima Nona Mostra Estatal em Moscou, Rodchenko apresentou cinquenta e sete desenhos feitos em uma pesquisa sobre a linha e o linearismo. Remetendo aos desenhos com régua e compasso de 1915, estes novos desenhos traziam uma tentativa de isolar a linha como única matéria de constituição do quadro. Foi dada, assim, à linha a mesma atenção que era dada à factura ${ }^{52}$. Um dos desdobramentos desta experimentação foi a transposição das linhas bidimensionais para objetos tridimensionais, dos quais apenas um que fez parte da exposição se manteve intacto, a Construção espacial no 12.

Já no período anterior à Primeira Guerra Mundial, muitos artistas da vanguarda se depararam com a questão da representação. A maioria optou, daquele momento em diante, pela abstração, mas de formas diversas e com consequências variadas. As linhas, enquanto matéria-prima pictórica, vinham se tornado cada vez mais instigantes aos artistas, sendo o foco de experimentos práticos e teóricos, inclusive para Rodchenko. Também para Kandinski era um tema na época, levando-o a publicar em 1919 um artigo na revista Iskusstvo [Arte] chamado Sobre a Linha. Rodchenko, por sua vez, redigiu um artigo-manifesto, Linearismo, em 1921 - tema cuja presença em seus cadernos de trabalho consta em anotações já de 1919. Nesse artigo ele apresentou ideias contrárias às de seu colega, que não partilhava da opção de Rodchenko por uma arte mais voltada para a questão material, o que fazia com que fosse considerado dissidente da arte politicamente orientada. Efetivamente, o uso da linha em Kandinski difere muito do uso que Rodchenko, Tatlin e Malevich fizeram. Kandinski, apesar de lançar mão de uma geometria também pronunciada - principalmente em Oval Vermelha, com a presença do trapezoide, um elemento caro ao Suprematismo - e do eixo deslocado na vertical, prioriza a composição estética harmoniosa, e não uma construção de elementos racionais. Na pintura de Kandinski, como nas de Malevich e Rodchenko, já havia o abandono de qualquer referência figurativa. $\bigcirc$ artista vinha buscando este abandono e o teorizou, quando morava em Munique, em seu livro Do espiritual na Arte, redigido em 1911, e publicado em tradução russa em 1914. No entanto, ao contrário das obras dos outros dois artistas, pode-se ver que Tristeza e Oval vermelha, embora sejam abstratas, ainda mantém forte expressividade pictórica. Esta expressividade estava totalmente ausente dos quadros suprematistas de Malevich. A solução que o artista encontrou para a representação
52. Embora o próprio artista tenha sempre defendido um caráter de avanço contínuo, que por vezes sua obra parece efetivamente demonstrar, e que alguns autores aceitam e corroboram, Hubertus Gassner afirma que há sim uma ruptura entre as obras em que Rodchenko desenvolveu pesquisas com a factura e estas com a linha. Diferente, por exemplo, de Benjamin Buchloh, que vê a predominância da factura por um período bem mais abrangente, quase até as fotomontagens. Para Gassner, a factura possuiu força no período em que o artista estava ligado a um ideário anarquista, pois ela é uma pintura com características mais individuais, enquanto que a pesquisa com a linha demonstraria preocupações mais coletivas, próprias ao ideário socialista. O que, de todo modo, se mantém é a ideia de experimentação, presente em praticamente toda a produção do artista nas décadas de 1910 e 1920. Ver Hubertus Gassner (1992) e Benjamin H. D. Buchloh (1984). 
53. Cf. John E. Bowlt (1988, p. 133), tradução da autora. Sobre a questão da representação na arte da vanguarda russa, Susan Buck-Morss aprofunda um pouco o debate afirmando que a geometrização não deixa de ser uma forma de representação - forma esta que estaria em consonância com a modernização que o ocidente sofria, e que a Rússia buscava alcançar. Ver Susan Buck-Morss (2000, p. 63).

54. Cf. Briony Fer. In: Briony Fer; David Batchelor e Paul Wood (1998, p. 113). nestas suas pinturas foi um tanto radical. No catálogo que acompanhou a exposição 0:10, onde foram apresentadas telas suprematistas pela primeira vez, Malevich afirmou:

A distorção foi levada pelos mais talentosos quase a desaparecer, mas não vai além dos limites do zero.

Mas eu transformei a mim mesmo no zero da forma e através do zero alcancei a criação, isto é, o suprematismo, o novo realismo da pintura - criação não-objetiva. (...)

Nosso mundo da arte se tornou novo, não-objetivo, puro.

Tudo desapareceu; uma massa de material sobrou da qual uma nova forma será construída. $\mathrm{Na}$ arte do suprematismo, formas vão viver, como todas as formas vivas da natureza.

Estas formas anunciam que o homem atingiu seu equilíbrio; ele deixou o nível da razão única e alcançou um de razão dupla.

(Razão utilitária e razão intuitiva.)

O novo realismo da pintura é da pintura precisamente porque não tem um realismo de montanhas, céu, água. ${ }^{53}$

De modo semelhante, Rodchenko procurou superar a questão da representação em suas pinturas como um cientista que fosse dissecando e analisando cada componente de um dado objeto. Com este espírito científico, racional, aplicado à arte, ele pretendeu ir despindo a pintura de cada componente pictórico, e chegou à conclusão de que o elemento fundamental seria a linha. Uma das telas em que se pode ver a pesquisa prática que intentou desenvolver sobre a linha é Construção n 92. Nela as linhas são desenhadas de uma forma muito marcada, auxiliada por instrumentos que the conferem precisão, ao contrário das pinturas de Kandinski, nas quais as linhas são feitas à mão livre, não sendo simplesmente retas, mas ângulos, tramas, traços arredondados. Rodchenko, em Linearismo, afirmou:

A linha imprecisa, trêmula, traçada pela mão, não pode ser comparada com a linha reta e precisa desenhada com o esquadro, reproduzindo exatamente o design. $\bigcirc$ trabalho artesanal deverá tentar tornar-se mais industrial. $\bigcirc$ desenho, como foi concebido no passado, perde seu valor e é transformado em diagrama ou em projeção geométrica. ${ }^{54}$

Para o artista, a tecnologia tinha um papel fundamental no âmbito da arte. Ao mesmo tempo que mediaria a mão do artista, livrando a obra de uma expressividade orgânica, ela deveria, também, permitir que a arte trabalhasse em nome da produção industrial.

Por outro lado, a opção de Kandinski pela intuição e não pela razão, pela harmonia de composição e não pela sólida construção, está em parte relacionada à sua ligação com a teosofia, teoria que se coloca entre a filosofia e a religião. Suas opções estéticas, em assuntos cruciais, batiam de frente com as de Rodchenko. Na época deste debate os dois artistas estavam em contato, pois Rodchenko e Stepanova moraram no apartamento de Kandinski entre 1919 e 
1920. Meses depois, Rodchenko seria o responsável pela expulsão do experiente e renomado colega da INKhUK, que declarou oficialmente desejar deixar de lado a arte "espiritualista", "mística" de Kandinski em favor da arte mais materialista defendida por Rodchenko55.

Apesar de os ânimos algumas vezes terem se exaltado, e de Rodchenko ter fomentado uma competição entre ele e os demais artistas no sentido de defender a própria arte como mais adequada ao mundo socialista, a partir de 1921 a vanguarda russa já não mostrou tanto vigor quanto antes. Christina Kiaer credita este arrefecimento em parte à implementação e desenvolvimento da NEP - Nova Política Econômica - que trouxe de volta à sociedade russa uma divisão de classes, bem como uma mediação do mercado entre a arte e seus patrocinadores, cujo julgamento estético era considerado retrógrado e característico do padrão burguês ${ }^{56}$. Calcados, como estavam, nos ideais do período do Comunismo de Guerra, os artistas da vanguarda não estariam agradando aos novos homens de negócios, os Nepmanianos, que seriam menos interessados nos experimentos radicais de uma arte beligerantemente socialista, do que nos modelos da arte tradicional. A tradição da pintura realista, que possuiu importância histórica dentro da arte russa predominante em muitas correntes artísticas - que jamais desapareceram mesmo durante o auge da vanguarda - correspondia melhor ao gosto destes Nepmanianos, bem como ao papel de veículo da propaganda estatal que o governo esperava da arte. Paulatinamente a partir da morte de Lênin em 1924, e de forma definitiva no início da década de 1930, o Partido Comunista proclamou o Realismo Socialista como estética oficial do regime. A partir daí, os artistas não gozaram mais de liberdade criativa e muitas das obras vanguardistas foram pejorativamente consideradas obras com preocupações exclusivamente formalistas, e portanto burguesas. Em uma fotografia da Exposição marxista experimental, realizada na Galeria Tretyakov em Moscou em 1931-2, pode-se ver, entre outras obras, Tristeza de Kandinski, uma das pinturas da série Preto sobre preto de Rodchenko e Suprematismo dinâmico e Quadrado Negro de Malevich ${ }^{57}$. Vê-se, porém, na parede, ao lado das pinturas, um cartaz onde se lê "A arte burguesa no beco sem saída do formalismo e da autonegação", indicando aberta e indistinta perseguição às mais diferentes correntes da vanguarda, exibida como contraexemplo.

\section{Composição, construção}

Kandinski foi chamado por Lunacharski, ainda dentro das primeiras medidas de reformulação do Estado socialista, para reorganizar e adequar o ensino de artes por meio do INKhUK, o Instituto de Cultura Artística, fundado em 1920. $\bigcirc$ que Kandinski propôs, no entanto, estava ligado à sua forma de compreender a arte como um processo intuitivo e subjetivo - pensamentos que ele já havia publicado em Do Espiritual na Arte, de 1911 , e que veio a se tornar a base de seu curso na Bauhaus alemã, para onde foi em dezembro de 1921 - e
55. Ver Alexander Lavrentiev (2005, p. 111-114); Leah Dickerman (1997, p. 29-30) e Magdalena Dabrowski. In: Peter Galassi; Magdalena Dabrowski e Leah Dickerman (1999, p. 34-35).

56. Ver Christina Kiaer (2005, p. 18-26).

57. Disponível em <http:// www.tretyakovgallery.ru/ en/museum/history/ gallery/1918_1941/>. Acessado em 05/09/2014. 
58. Em um relatório da própria INKhUK de 1923 lêse: "Lá foi encontrada uma divergência fundamental entre Kandinski e alguns dos membros do Instituto. A abordagem psicológica de Kandisnki divergiu fortemente do ponto de vista dos que consideram o 'objeto' material, auto contido, como a substancia da criação. Kandinski partiu e Rodchenko, Stepanova, Babichev e Bryusova entraram na administração". Cf. Christina Lodder (1987, p. 81).

59. Cf. Hubertus Gassner (1992, p. 299), tradução da autora.

60. Sobre a exposição do grupo Obmoku, em Moscou, 1921, em que Rodchenko exibiu sua Construção espacial $n^{\circ} 12$, ver Briony Fer. In: Briony Fer; David Batchelor e Paul Wood (1998, p. 91-92).

61. Ver Ibidem (p. 100).

62. Cf. Ibidem (p. 105-106). encontrou forte resistência junto a outros membros do Instituto, que depois vieram a formar o grupo construtivista, do qual Rodchenko fez parte ${ }^{58}$. Após a saída de Kandinski, os debates na INKhUK buscaram estabelecer um novo programa para a instituição. A 'arte pura', como por exemplo a pintura de cavalete, foi excluída de imediato. Deste modo, Stepanova declarou que "Uma vez expurgada de excrecências estéticas, filosóficas e religiosas, a arte nos deixa suas fundações materiais, as quais a partir de então serão organizadas pela produção intelectual", afirmando em seguida que "O princípio organizacional é um expediente do Construtivismo, no qual tecnologia e pensamento experimental tomam o lugar da estética" 59

Nos debates, duas posições contrárias emergiram, e o foco da discussão tornou-se a contraposição entre "composição" e "construção". A "composição" estava ligada à ideia de que seria possível manter uma arte de preocupações formais, estéticas, considerada pelos seus oponentes como burguesa. "Construção" era ligada à noção de construções utilitárias e à produção industrial. Vigorava então a fase de laboratório, assim chamada por alguns artistas do grupo, para denominar o período de experimentação artística pela qual passavam. Fase de laboratório, bem como o próprio Construtivismo, nome do grupo que Rodchenko ajudaria a criar em seguida, eram termos ligados propositalmente à ciência - em detrimento da arte tradicional: a pintura de cavalete e a escultura decorativa -e indicava o intuito de experimentar com os materiais e formas. Foi também nesta fase substituída a denominação de "obra de arte" para as peças produzidas pelos artistas engajados, e em seu lugar foi adotado o termo "construção"00. Era o ano de 1921, quando a produção na Rússia começava a ser retomada por meio da introdução da NEP. As palavras russas, correlatas a "construção", usadas pelos construtivistas para definirem suas obras, eram originadas da arquitetura e da construção civil: konstruktsiya e konstruirovaniebl. Também a própria palavra "construção" possuía um sentido político muito forte, pois foi usada por Lênin em seus discursos no sentido de promover "a construção do socialismo" por meio do legado do capitalismo, ou seja, por meio dos especialistas burgueses. Assim, no programa do Grupo de Trabalho Construtivista, 1921, havia a referência ao

Papel a ser exercido na "edificação" de uma cultura socialista, ecoando o uso constante feito por Lênin da metáfora da "construção comunista". Lênin propunha que o comunismo deveria explorar, para seus próprios fins, a ciência, a tecnologia e a cultura legadas pelo capitalismo: "devemos construir o socialismo a partir dessa cultura, não temos outro material - nós temos burgueses especialistas e nada mais. Não temos outros tijolos com os quais construir"62.

Sem deixar de lado as mostras e exposições como locais de apresentação e fóruns de debate, e sem poder abrir mão de certas características imediatamente relacionadas à arte tradicional - como o suporte, por exemplo a tela, e certos materiais, como a tinta - os construtivistas buscavam, de forma um tanto paradoxal, cada vez mais se afastar da noção de "obra de arte", refugiandose nas "construções", que questionavam o quanto podiam essas características. 
Assim, vê-se nos relevos de Tatlin o uso de metal e arame, em pinturas de Rodchenko o uso de esquadro e régua, e em telas de Malevich a negação do figurativo e a supressão de elementos pictóricos.

Por vezes, o apelo à construção foi tomado literalmente pelos artistas de vanguarda, e muitos deles, inclusive Rodchenko a partir do ano de 1921 , fizeram projetos arquitetônicos para as cidades russas, muitas vezes denominados de "arquitetura utópica", como o monumento de Tatlin. Outras vezes ainda, os artistas engajaram-se não só com a construção do comunismo, mas também de um mundo inteiramente novo, como foi visto anteriormente nos manifestos programáticos dos construtivistas e do LEF, e que também foi o caso de Rodchenko.

Os debates na INKhUK estenderam-se de tal forma, que as posições conflitantes não encontraram um meio termo, o que culminou com a formação de um grupo separado no interior do Instituto, o Primeiro Grupo de Trabalho Construtivista, formado ainda em 1921 por A. Gan. Varvara Stepanova e Rodchenko. Em 1922 uniram-se a eles os irmãos Stenberg, Konstantin Medunetski e Karl loganson. Os trabalhos deste grupo dissidente foram expostos na terceira exposição do OBMOKhU, e, segundo Christina Lodder, apresentaram forte ênfase na precisão, clareza e economia oferecidas pelas formas geométricas. A relação com a tecnologia seria, segundo a autora, ressaltada por estas características, que teriam sido incitadas pelo Monumento à Terceira Internacional de Tatlin ${ }^{63}$.

A noção de tecnologia que passou a fazer parte da agenda dos construtivistas seria fundamental mais tarde na adoção da fotografia por Rodchenko. Ela tem origem tanto nas pesquisas formais quanto no desejo engajado dos artistas de que a arte penetrasse no cotidiano, facilitando-o e melhorando-o, uma arte que estivesse ligada à produção industrial. Não havia na concepção desses artistas, portanto, pesquisas puramente formais. A forma e o conteúdo da obra deveriam ser mais do que nunca inseparáveis.

Assim, a partir da ênfase no aparato material que engendra o quadro, sugerida por Tatlin, e com a busca do elementar dentro da forma sugerida por Malevich, Rodchenko trabalhou muito próximo ao conceito de factura, a textura ou superfície do quadro. Para ele, como também para muitos artistas ligados às vanguardas mesmo antes de 1917, o que interessava na pintura era a sua qualidade material, física, e não a imagem representacional, que seria uma característica de ilusão. Daí o interesse na superfície da tela, inclusive nas cores e qualidades das tintas, que para Nicolai Tarabukin, crítico e teórico vanguardista, era o que dava significado à pintura não objetiva ${ }^{64}$.

A factura fazia parte da teoria linguística dos formalistas, que a julgavam um fator importante em todas as artes. Era a valorização do material que engendra a obra, e que ao mesmo tempo the dá significado. Segundo Magdalena Dabrowski "A fisicalidade da pintura como um objeto, e a fisicalidade da execução tornaramse o novo critério na apreciação da obra de arte. $\bigcirc$ material em si - neste caso a tinta - e o método de sua aplicação influenciam a percepção do objeto"65. A
63. Ver Christina Lodder (1987, p. 72).

64. N. Tarabukin fez esta afirmação no ensaio For the Theory of Painting, de 1916, mas publicado apenas em 1923. Cf. Magdalena Dabrowski. In: Peter Galassi; Magdalena Dabrowski e Leah Dickerman (1999, p. 26).

65. Cf. Magdalena Dabrowski. In: Peter Galassi; Magdalena Dabrowski e Leah Dickerman (1999, p. 30). 
66. Ver Benjamin Buchloh (1984, p. 53-54).

67. Esta exposição é considerada um marco na carreira de Rodchenko. Ver John E. Bowlt. In: Alexander Lavrentiev (2005, p. 13) e Magdalena Dabrowski e Leah Dickerman (1999, p. $63,101)$.

68. Sobre estas telas, ele afirmou, em escrito de 1939: "Eu reduzi a pintura à sua conclusão lógica e expus três telas: vermelha, azul e amarela. Eu afirmei: está tudo terminado. Cores primarias. Todo plano é um plano e não deverá haver representação" Cf. Magdalena Dabrowski. In: Magdalena Dabrowski; Leah Dickerman (1999, p. 43), tradução da autora. opção pela factura é assim plena de significados, pois indica também a preocupação com as reações do público da arte, considerado pelo artista no momento da execução da obra, e pensado como público de massas. $\bigcirc$ conceito de factura e o de construção são dois lados de uma mesma moeda na arte engajada dos construtivistas russos.

Do mesmo modo, segundo o crítico Benjamin Buchloh, a ênfase na factura tinha forte ligação com o processo de industrialização e a tentativa de retomada da produção estagnada - seria seu correlato estético, denunciando novamente a ligação que os artistas procuravam manter entre sua produção e a transformação da sociedade, ou seja, a tarefa social que a arte se impôs então ${ }^{66}$. Por trás deste questionamento da própria ideia de arte, percebe-se que a preocupação dos artistas girava em torno da indagação acerca do papel da arte e do artista dentro de um Estado socialista, que ainda precisava lutar por sua efetiva consolidação. Uma das formas encontradas de manter a presença da arte coerente dentro deste Estado foi dotá-la de uma característica pedagógica, de instrução das massas e de veiculação de um ideário. Para tanto, ela deveria trazer em seu próprio engendramento uma rígida coerência com os ideais da Revolução Russa. Daí a busca de instrumentos, materiais e técnicas que permitissem manter tal coerência, como a régua e o compasso, e a factura.

Rodchenko desenvolveu sua arte, principalmente a partir de 1918, como um soldado na frente de batalha, e também como um cientista no laboratório. Procurou afastar-se cada vez mais do que entendia como arte tradicional, por meio das noções de construção e de factura. É, portanto, significativo que a grande maioria dos autores que estudam o período identifique como crucial o momento em que Rodchenko se desvencilhou de uma das principais manifestações desta arte tradicional, declarando o fim da 'pintura de cavalete': a exposição 5x5=25, realizada em Moscou em 192167. Nesta ocasião, ele apresentou um tríptico de telas: Puro azul, Puro vermelho e Puro amarelo, que traziam, cada uma, apenas a cor do tífulo cobrindo-as. $\mathrm{Na}$ concepção do artista, ele levava assim às últimas consequências a experimentação iniciada pelos primeiros contatos com Malevich e Tatlin, a experimentação de análise e desnudamento pictórico que havia conduzido nestes anos. Tais pinturas foram consideradas por ele a sentença de morte deste meio ${ }^{68}$ : das telas cobertas uniformemente, cada uma com uma das cores primárias, não se podia ir além na desconstrução pictórica.

De modo tanto experimental quanto combativo, o objetivo declarado por Rodchenko era abalar não só a noção de obra de arte, mas também o próprio papel do artista, que, destituído pelos construtivistas do lugar privilegiado de gênio dotado de arrebatadoras inspirações, deveria agora ocupar seu lugar na construção do novo mundo e do novo homem socialistas, porém de uma forma artística, criativa e inovadora. Esta noção apareceu de forma mais clara no artigo já mencionado de Ossip Brik, presente na primeira edição de Lef, de 1923, V proizvodstvo! [À produção!]: 
Rodchenko vê que o problema do artista não é a apreensão abstrata de cor e forma, mas a habilidade prática de resolver qualquer tarefa de dar forma a um objeto concreto. Rodchenko sabe que não existem leis imutáveis de construção, mas que cada tarefa deve ser resolvida de maneira nova, a partir de condições definidas pelo caso específico. ...

Rodchenko é paciente. Ele vai esperar; enquanto isso ele está fazendo o que pode - ele está revolucionando o gosto, limpando o caminho para a cultura futura, não-estética, material e oportuna. 69

seu constante "evoluir" em direção a este fim parece, dentro desse discurso, dotar a arte de uma necessidade histórica correlata à necessidade histórica da Revolução no pensamento marxista e à compreensão de que o Estado comunista seria o ponto de chegada inevitável70. Após a criação de seu tríptico, Rodchenko acreditou estar dando mais um passo em direção a esta sua concepção de evolução da arte. Foi, assim, o momento de virada em que o meio artístico tradicional foi trocado por meios técnicos, pois já em 1922 ele se voltou para a fotomontagem, e em 1924, para a fotografia.

A imagem técnica e retorno da representação

A fotomontagem possibilitou a Rodchenko novamente trabalhar com a representação em sua arte sem, no entanto, usar o paradigma de representação tradicional, que considerava burguês. Suas obras puderam se aproximar mais do que nunca do que ele identificava com o real, o cotidiano, e, em virtude da fidelidade da representação fotográfica, visavam ser também mais próximas e inteligíveis para as massas. Em 1922, com o decreto de Lênin concernente ao cinema, de 17 de janeiro, o Partido Comunista começava a colocar alguma pressão em grupos artísticos para que estes se voltassem na direção de uma arte mais realista. Tal decreto visou à criação de uma indústria cinematográfica soviética que estaria incumbida de propagar os ideais e valores comunistas por meio de seus filmes e documentários. No mesmo texto, Lênin referiu-se brevemente à fotografia, exultando a produção de imagens com os mesmos intentos dos filmes de propaganda, estipulando que "fotografias de interesse para propaganda devem ser apresentadas com as legendas apropriadas"71. Estas novas diretrizes podem ter colaborado para que Rodchenko julgasse ter esgotado as possibilidades da arte abstrata - principalmente, mas não só, a pintura. Muitas vezes compreendida como uma resposta às pressões governamentais, a revalorização da representação na arte de Rodchenko - especialmente por meios técnicos como o cinema e a fotografia - pode ser também interpretada como uma rápida compreensão e voluntária adoção da defesa da propaganda feita por Lênin.

Data dos meses seguintes à abertura da Rússia para o exterior - no início da década de 1920, quando os conflitos que se seguiram à Revolução de Outubro amainaram - a adoção da fotomontagem por artistas russos. As primeiras fotomontagens realizadas foram praticamente simultâneas às de artistas alemães:
69. Cf. Ossip Brik, $\grave{A}$ Produção. Cf. Leah Dickerman (1997, p. 3), tradução da autora.

70. Como já foi ressaltado, Hubertus Gassner afirma que houve uma clara ruptura entre a obra de Rodchenko que se ateve mais à factura - como as pinturas da série Preto sobre preto - e as mais calcadas no racionalismo - como as que exploraram a linha e as que figuraram na exposição do OBMOKhU. Rodchenko, porém, assim como outros artistas da vanguarda, não estaria interessado em admitir tal ruptura, defendendo sempre o discurso da evolução da sua arte em caminho racionalmente direto. Ver Hubertus Gassner (1992, p. 311).

71. Cf. Christina Lodder (2000, p. 293). 
72. Ver Christopher Phillips (1989, p. 212).

73. Cf. Dawn Ades (1976, p. 12), tradução da autora.

74. Cf. Ibidem, p. 13, tradução da autora.

75. Cf. Dawn Ades (1976, p. 70-71). em 1922, Maiakovski trouxe de Berlim fotomontagens de George Grosz e John Hearffield, entre outros, que foram vistas por Rodchenko e por outros membros do grupo LEF72. Raoul Hausmann reclama para si, e para o grupo dadaísta do qual fazia parte, a paternidade da técnica por meio da paternidade do termo fotomontagem:

Tomado por zelo inovador, eu também precisava de um nome para esta técnica, e em acordo com George Grosz, John Hearffield, Johannes Baader e Hannah Hoch, nós decidimos chamar estes trabalhos de fotomontagens. Este termo traduz nossa aversão em bancar o artista, e, pensando em nós mesmos como engenheiros (daí nossa preferência por macacões de trabalhadores) nós pretendemos construir, montar nossas obras. ${ }^{73}$

Pode-se perceber pela declaração de Hausmann que a fotomontagem foi escolhida então como meio artístico privilegiado por motivos em parte semelhantes aos dos construtivistas russos do mesmo período, como Rodchenko. A forte presença da ideia de construção é fundamental. Assim como os russos, esses dadaístas diziam-se engenheiros, e declaravam a preferência por vestirem-se com uniformes de operários. Rodchenko também usava um uniforme semelhante, um macacão que ele desenhou e que Stepanova confeccionou. Mais importante, no entanto, é a negação da ideia de artista tradicional, bem como da ideia de obra de arte. Unindo partes de imagens que já existiam e que foram produzidas com outras finalidades, na maioria dos casos publicadas em veículos de comunicação de massas, o artista se destituiria do papel de agente criador, de inspirado imitador da natureza, e passaria a ocupar o lugar de um técnico, apto a lidar com maquinário tecnológico da modernidade.

Deste modo, Hannah Höch afirmou: "Todo nosso propósito é integrar objetos do mundo das máquinas e da indústria no mundo da arte"74. Também para Rodchenko e seus colegas a fotomontagem simbolizava a presença da tecnologia e da modernidade. Porém, poderia se supor que se a declaração de Hannah Höch fosse feita por um construtivista russo, ela seria inversa: o objetivo deles seria menos integrar objetos pertencentes ao mundo da máquina e da indústria na arte, do que integrar a arte ao mundo da tecnologia e da indústria.

O desenvolvimento da fotomontagem, no geral, tem estreita relação com o desenvolvimento dos veículos impressos de comunicação de massas, e em especial dos jornais e revistas ilustradas, pois muitos artistas utilizavam-se de figuras recortadas destes como ready-made e matéria-prima. Também nestes jornais e revistas ilustradas esta nova arte era divulgada, como nas revistas alemãs AlZ e Neve Jugend, a húngara Ma, que depois mudou-se para Viena, a Vechsh, publicada por El Lissitzki em russo, alemão e francês, e muitas outras. Na Rússia, a Lef 75 foi uma das principais revistas a reconhecer a importância das fotomontagens e publicá-las, sendo Rodchenko um dos principais colaboradores neste campo.

Tretyakov, membro do grupo LEF, referindo-se tanto às fotomontagens russas quanto às alemãs, afirmou: "Se a fotografia, sob a influência do texto, 
expressa não apenas o fato que ela mostra, mas também a tendência social expressa pelo fato, então ela já é uma fotomontagem"76. Ou seja, segundo ele poderia se criar uma fotomontagem somente com uma fotografia inalterada, desde que esta fotografia carregasse um conteúdo político, em diálogo com a matéria escrita da revista ou jornal em que estivesse publicada. A ligação com o âmbito político estaria, assim, na base mesma da concepção de fotomontagem ${ }^{77}$. Para os artistas dadaístas, esta ligação também existia, na medida em que a fotomontagem era usada para questionar a posição privilegiada - elitista - da arte: era uma "anti-arte" que deveria chocar, agitando e destruindo a complacência europeia do período seguinte à Primeira Guerra Mundial.

Durante a Feira Internacional Dada, realizada em 1920 em Berlim, Raoul Hausmann apresentou sua fotomontagem Tatlin em casa (1920). Nesta exposição, os artistas incluíram um cartaz com o seguinte slogan: "A arte está morta - vida longa à arte-máquina de Tatlin" (Figura 4), atestando a ligação entre os movimentos dadaísta e construtivista. Anos depois desta ocasião, Hausmann relembrou o processo criativo da elaboração de sua obra:

Ter a ideia para uma imagem e encontrar as fotos que podem expressa-la são duas coisas diferentes... Um dia, eu estava folheando aleatoriamente uma revista norte-americana. De repente eu fui surpreendido pelo rosto de um homem desconhecido, e por algum motivo eu fiz uma associação automática entre ele e o russo Tatlin, o criador da arte mecânica. Mas eu preferi retratar um homem que não tinha nada em sua cabeça a não ser máquinas, cilindros automobilísticos, freios e volantes...

Sim, mas isso não era suficiente. Este homem deve também pensar em termos de grande maquinário. Eu procurei entre as minhas fotos, e achei a popa de um navio com uma grande hélice propulsora, e coloquei ela em pé contra a parede ao fundo.

Não gostaria este homem também de viajar? Aqui está o mapa da Pomerania, na parede à esquerda.

Tatlin certamente não era rico, então eu recortei de um jornal francês um homem de sobrancelhas franzidas, andando e virando para fora seus bolsos vazios. Como ele pode pagar seus impostos?

Bom. Mas agora, eu precisava de alguma coisa na direita. Eu desenhei um manequim de alfaiate em minha imagem. Ainda não era o suficiente. Eu cortei de um livro de anatomia órgãos internos do corpo humano e os coloquei no torso do manequim. Aos pés, um extintor de incêndio.

Eu olhei mais uma vez.

Não, não havia mais nada para mudar.

Estava bom, estava terminado! ${ }^{78}$

Percebem-se nesta declaração algumas concepções que não faziam parte do discurso de Rodchenko e do LEF. A presença de associações e relações não racionais, que sobrepujam a noção de construção absolutamente planejada em favor da criação de uma atmosfera mais estética, e a fuga da concepção fundamental dos artistas russos, de que o engendramento da imagem faz parte de
76. Ibidem (p. 17), tradução da autora.

77. A ligação da montagem - não só a fotomontagem, mas também a montagem cinematográfica, com quem ela possui grande afinidade - com a política foi, mais tarde, elaborada por Walter Benjamin em Paris, Capital do Século XIX, quando atestou a união entre forma e ideia, e a possibilidade de a obra de arte interferir no mundo, na própria feitura da história enquanto conhecimento. Ver Georges Didi-Huberman (2005, p. 191-192).

78. Cf. Beaumont Newhall (2002, p. 211), tradução da autora. 
sua estética final - daí a importância da factura, por exemplo - são algumas divergências com o construtivismo que podem ser identificadas na descrição do processo criativo de Hausmann.

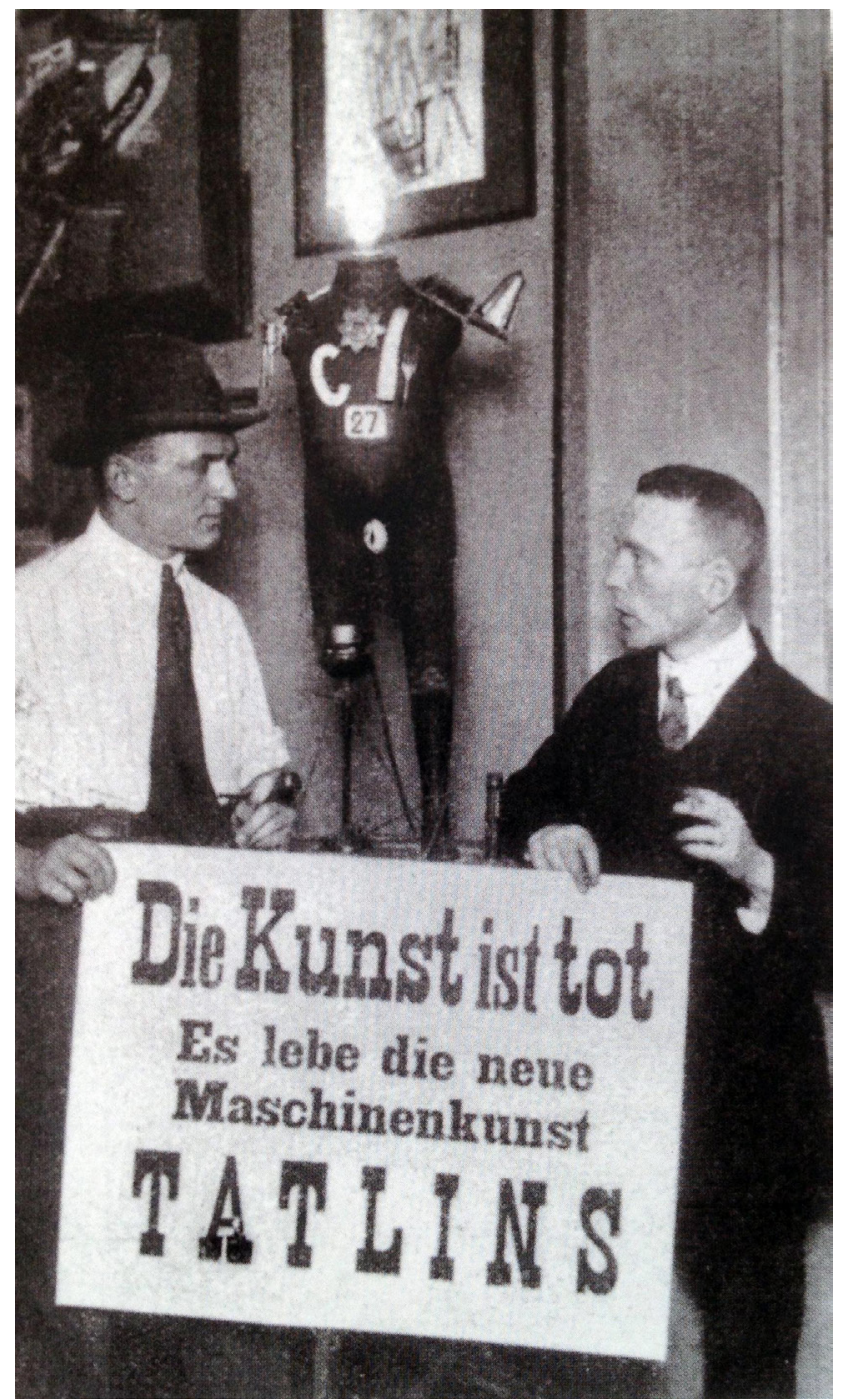

Figura 4 - George Grosz e John Heartfield na Feira Internacional Dada em Berlim, 1920. Disponível em: <http://commons.wikimedia.org/wiki/File:Die_Kunst_ist_tot.Tatlin.jpg>.

Na sua quarta edição, de 1924, a revista Lef trouxe um artigo em que as características da fotomontagem como meio artístico eram exaltadas. As ilustrações que Rodchenko havia criado para o livro de poesias de Maiakovski Sobre Isso [Pro Eto] foram consideradas como um dos paradigmas deste meio na Rússia, e as do grupo dadaísta foram citadas como exemplos do que se produzia no ocidente. $\bigcirc$ artigo não foi assinado, indicando que ele refletia uma posição comum do próprio grupo: 
Fotomontagem nós entendemos que quer dizer a utilização de fotografias como um meio visual. Uma combinação de instantâneos toma o lugar da composição em uma representação gráfica.

O que esta substituição significa é que o instantâneo fotográfico não é o rascunho de um fato visual, mas seu registro preciso. Esta precisão e caráter documentário do instantâneo tem um impacto no observador que uma representação gráfica jamais pode causar.

Um pôster sobre o tema da fome composto de instantâneos de pessoas famintas causa uma impressão muito mais forte do que uma que traga desenhos do mesmo.

Uma propaganda com a fotografia do objeto anunciado é mais efetiva que um desenho do mesmo tema.

Fotografias de cidades, paisagens, rostos, dão ao observador mil vezes mais do que pinturas destes assuntos.

Até hoje, fotografia profissional, isto é, artística, se esforçou em imitar pintura e desenho; como consequência, a reprodução fotográfica era fraca e não revelava seu potencial inerente. Fotógrafos presumiam que quanto mais um instantâneo se parecesse com uma pintura, mais artístico ele seria. Na realidade, o inverso era verdadeiro: quanto mais artístico, pior ele era. As fotografias possuem suas próprias possibilidades para montagem - que não têm nada a ver com uma composição de pintura. Isto deve ser revelado.

Aqui na Rússia nós podemos apontar para o trabalho de Rodchenko como modelos de fotomontagens - em suas capas, pôsteres, publicidade e ilustrações (Sobre isso de Maiakovski).

No ocidente os trabalhos de George Grosz e outros dadaístas são representativos da fotomontagem. ${ }^{79}$

As atenções já começavam então a se voltar para a fotografia como um meio autônomo, e a sua pretensa capacidade de mostrar a realidade sem cair na pintura realista do século anterior foi o fator mais enaltecido: as fotografias trariam antes a realidade do que símbolos, e esta característica lhes daria uma maior importância política. Novamente a composição tradicional foi substituída, e desta vez por uma combinação de imagens técnicas, ou seja, imagens produzidas e reproduzidas mecanicamente.

Para Sobre Isso, Rodchenko criou oito fotomontagens a partir de imagens retiradas de jornais e revistas, e de fotografias de Maiakovski e de Lilia Brik (1893-1978), amante do poeta e para quem o livro foi dedicado. As imagens que ele produziu têm importância dentro da história deste meio, naquele momento ainda em seu início. Elas têm forte poder narrativo, embora tenham se mantido fiéis ao tom onírico do poema escrito por Maiakovski. $\bigcirc$ artista se beneficiou da possibilidade oferecida pelas colagens de reorganizar o mundo visível, mudando escalas de tamanho e criando metáforas, e o fez em consonância com o desenrolar do texto. A capa é um retrato de Lilia, e cada uma das ilustrações é acompanhada pelas seguintes frases do poema, na tradução de Paulo Cypriano intitulada Isto:
79. Cf. Christopher Phillips (1989, p. 211-212), tradução da autora. Grifos no original. Este artigo foi publicado na Lef n. 4, 1924, sem indicação do autor. Há várias opiniões entre a crítica atual, divergentes, sobre quem o escreveu. Para Phillips, o autor teria sido Gustav Klutsis. Segundo Leah Dickerman, em Aleksandr Rodchenko's Camera-Eye (p. 4), teria sido Ossip Brik. Para Benjamin Buchloh, o texto seria atribuído por alguns pesquisadores ao próprio Rodchenko. Ver Benjamin H. D. Buchloh (1984, p. 60) 
80. Cf. Vladimir Maiakovski (2002). As fotomontagens publicadas no livro Gráfica Utópica... podem ser consultadas em <http:// artsearch.nga.gov.au/Detail. cfm?IMG=78337_b\&IRN=78 $337 \& v I D=3>$. Acessado em 05/09/2014.

81. Para uma análise mais detalhada desta imagem, ver Christina Kiaer (2005, p. 151-155).
Na cama, ela, deitada./Ele -/Sobre a mesa. O telefone

Rastejava/pelo fio/o monstro dos tempos trogloditas/do ciúme que rói.

Com as patas eu tapo os ouvidos./Amassa-os em vão!/Eu escuto/a minha/a minha própria voz/a faca da voz fura-me as patas.

E isso está assim parado há séculos/como era/não açoitam./E não move-se o jumento do dia-a-dia.

E novamente/as cadentes estepes das paredes/ao alcance dos ouvidos tinem e suspiram no "two-step".

Tento o equilíbrio, /agito terrivelmente os braços

Quatro vezes envelhecerei, quatro vezes rejuvenescido

E ela/- ela amava os bichos -/também adentra o jardim. ${ }^{80}$

Este poema é em certa medida autobiográfico, pois Maiakovski naquele momento estava separado de Lilia. Rodchenko usou retratos dela para a personagem feminina, e retratos do poeta para o personagem masculino. A história mostra um triste amante e suas desventuras com o ciúme e a solidão. As imagens são muito geométricas, lembrando as obras futuristas. Há uma clara preocupação com a construção das figuras sobrepostas, apesar do aparente caos gerado pela profusão de imagens, que reforça o caráter narrativo destas fotomontagens. Assim, quando o poema relata o sofrimento do amante rejeitado, com ciúmes, ao telefone, a ilustração de Rodchenko utiliza-se do deslocamento na diagonal, caro aos artistas da vanguarda, e apresenta no canto inferior esquerdo uma senhora segurando o telefone, cuja linha segue sobre o skyline de uma cidade colocado em diagonal até o limite superior oposto - onde se vê o número de telefone da casa de Brik - que alcança o poeta, cujo telefone colossal é segurado por um dinossauro. E quando o personagem de Maiakovski revela sua discordância com a tradição, a vida doméstica tradicional e os costumes da sociedade, a ilustração mostra vários utensílios domésticos como colheres, uma faca, xícara, bandeja, a silhueta de um casal sentado à mesa, um senhor gordo e calvo, vestido à maneira burguesa, etc. Estes itens parecem representar o antigo byt, modo de vida vigente antes da revolução de outubro e que deveria ser totalmente substituído pelo novyi byt, um novo modo de vida em acordo com o socialismo, ao qual Maiakovski apresenta-se incorporado, com uma boina usada por trabalhadores e um sobretudo, sentado atrás de tais objetos ${ }^{81}$. Na última estrofe do poema, a fotomontagem mostra o rosto de Lilia em destaque, e várias imagens de animais unidas, sem qualquer preocupação com a relação entre o tamanho dos objetos e a perspectiva das cenas, mas fiel à narrativa do poema, em que o poeta narrador imagina-se transformado em um animal pelo ciúme, e levado ao zoológico, onde sua amada talvez o visitasse.

Todas estas imagens aparecem em escalas discrepantes, em um aparente desordenamento, mas com um grande poder narrativo, utilizando-se das transgressões espaciais para melhor contar, explicitar até, o que diz Maiakovski. Ao contrário, a já mencionada montagem de Hausmann criou uma determinada sensação espacial, uma perspectiva, um local onde se passa a ação. Em Tatlin em casa percebe-se uma sala, 
o artista tendo pintado um chão de madeira, paredes e móveis. Também há um certo respeito pelas escalas: o que está mais à frente é maior, o que está atrás menor. Rodchenko, no entanto, subverteu esta sensação espacial - por exemplo fazendo com que a linha telefônica atravessasse toda Moscou, representada por uma vista fotográfica, e chegasse ao ouvido de Maiakovski por meio de um aparelho de telefone maior que ele próprio. As imagens sobrepostas na montagem reproduzida na página 21 do livro (Figura 5), que remetem a cenas e objetos domésticos, correspondem-se menos com a fotomontagem de Hausmann do que com a de Hannah Höch, outra expoente dadaísta deste meio. Uma de suas obras mais conhecida, Cortado com uma faca de bolo, de 1919-1920, que também esteve presente na Feira Internacional Dada juntamente com Tatlin em casa, apresenta a mesma fragmentação que a imagem de Rodchenko feita para Sobre isso. Nela diversas figuras sem correspondência de tamanho ou perspectiva são sobrepostas. A grande maioria, no entanto, como em Rodchenko, é inteligível, assim como as frases coladas são legíveis, apesar das sobreposições. Estas frases poderiam ser consideradas como legendas da imagem, assim como as frases do poema no livro de Maiakovski poderiam ser consideradas a legenda dessas montagens. Na fotomontagem de Höch, figuras humanas dividem o espaço com peças de máquinas, alguns animais e cenas urbanas, gerando uma imagem única cujo caráter caótico acaba por se transformar justamente em sua composição estética. Na de Rodchenko, apesar de também um tanto caótica, as junções permitem uma maior associação entre as imagens, tornandose de certo modo mais imbuída de caráter narrativo do que a de Höch. Para essas fotomontagens, assim como no caso de outras que se seguiriam, Rodchenko contou com a ajuda de Abram Sterenberg, a quem encomendava as fotografias específicas que necessitava, uma vez que ele próprio ainda não fotografava.

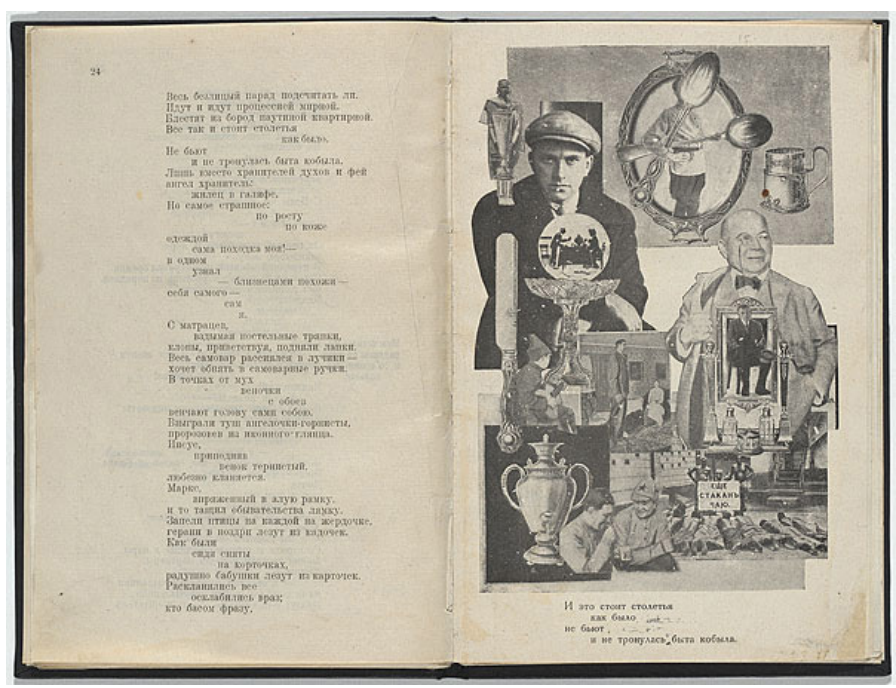

Figura 5 - Página dupla do livro Sobre Isso, de Mayakovsky, com Fotomontagem de Rodchenko, Ed. Gosizdat 1923. 
82 Rodchenko encomendava as fotografias com Abram Sterenberg, mas possuía também uma coleção de recortes de revistas e de um arquivo pessoal de imagens da Revolução. Ver Peter Galassi. In: Peter Galassi; Magdalena Dabrowski e Leah Dickerman (1997, p. 207). Sobre seu contato com o fazer fotográfico, propiciado pela fotomontagem, Rodchenko afirma, em texto de 1940 "Em relação com meu trabalho com fotomontagem, eu também comecei a fotografar - algumas vezes algo precisava muito ser refotografado, ampliado, reduzido... Eu comprei duas câmeras para mim - uma 13x18 com tripla extensão, com uma Dagor - uma câmera para fotografar novamente reproduções - e uma Kodak compacta”. Cf. Aleksandr Rodchenko. In: Alexander Lavrentiev (2005, p. 239), tradução da autora.

83. Michel Frizot e Andréas Haus, ao traçar o caminho feito por Rodchenko desde a fotomontagem até a fotografia, fazem uma elucidativa comparação com o fotografo húngaro Moholy-Nagy. In: Michel Frizot (1998, p. 438).

84. Ver Aleksandr Rodchenko. In: Alexander Lavrentiev (2005, p. 238).

85. Cf. Vladimir Maiakovski. In: Boris Schnaiderman (1971, p. 127 e 129).

86. Cf. Leah Dickerman. In: Peter Galassi; Magdalena Dabrowski e Leah Dickerman (1999, p. 69).
O ofício da fotomontagem, no entanto, o levou diretamente ao coração da reprodutibilidade técnica que a fotografia oferecia - característica própria deste meio e das mais valorizadas por Rodchenko e pela fotografia moderna no geral, por questionar o papel da arte tradicional. Uma vez que toda impressão do negativo gera uma fotografia "original", não faz sentido pensar as fotografias ou fotomontagens nestes termos, tampouco pensar o artista como criador de algo raro e único. Ele comprou duas câmeras fotográficas para melhor manipular as imagens que possuía ${ }^{82}$. A aproximação com a fotomontagem forneceu-the, assim, o contato com a técnica do fazer fotográfico ${ }^{83}$, que teve desdobramentos em seu processo criativo neste meio artístico, valorizando não só a reprodutibilidade técnica, mas também um olhar mais livre quanto ao ponto de vista, a liberdade de escalas e de referências, e a ideia da imagem como um instrumento, não uma obra de arte acabada e intocável.

Rodchenko teve a chance de, entre 1923 e 1926, desenvolver sua técnica tipográfica para realizar cartazes publicitários para produtos de consumo. Entre 1923 e 1925 ele manteve uma sociedade com Maiakovski, que era responsável por escrever as frases de anúncio. A sociedade entre os vanguardistas produziu não só cartazes para afixar na parede, mas também anúncios para fachadas de prédios e quiosques, papéis de embrulho de doces e produtos comestíveis, entre outros.

O empreendimento publicitário de Rodchenko e Maiakovski prosperou por um tempo - na estimativa do primeiro, eles produziram cerca de cinquenta anúncios nos dois primeiros anos, o período de maior atividade, além de outros meios publicitários ${ }^{84}$ - mantendo contratos com diferentes empresas estatais, como a Dobrolet, empresa de aviação, e a Mosselprom, loja de departamentos. Para ambos, além de um ganha-pão, esta atividade teria, conforme pensavam, objetivo político, pois ao encorajar o consumo da população no comércio estatal, eles estariam não só colaborando com a tomada de consciência das massas em favor do aumento da produção, mas também o fazendo por meio de uma nova forma de comunicação social, que seria mais moderna e revolucionária. Maiakovski chegou a afirmar: "Conhecemos muito bem a força da agitação. Em toda vitória militar, em todo êxito econômico, 9/10 são devidos à habilidade e força de nossa agitação"; e, mais adiante, "Não devemos deixar esta arma, a agitação comercial, nas mãos do nepmaniano, nem do burguês estrangeiro. Na URSS, tudo deve atuar no sentido do bem-estar do proletário. Pensem na publicidade!" 85 . Deste modo, um desses cartazes publicitários mais conhecidos, de 1923, é para a Dobrolet, onde se lê: "Todos... Todos... Todos... Aquele que não possui ações da Dobrolet não é um cidadão da URSS"86. Vigorava naquele momento a Nova Política Econômica, que deu abertura a este tipo de publicidade, pois incentivou - consumo como saída para a estagnação da produção industrial. Para Rodchenko e Maiakovski, fomentar o consumo da população direcionando-o para as fábricas e lojas estatais, ao mesmo tempo que propiciaria o aumento da produção das empresas estatizadas, diminuiria o sucesso dos empreendimentos 
privados que os membros da recém-recomposta classe dos empresários, os homens da NEP, vinham desenvolvendo. Estes eram vistos como a antítese ideológica dos artistas da vanguarda, por visarem o lucro por meio da manutenção do gosto tradicional do mercado ${ }^{87}$.

Em um país onde era grande o número de analfabetos, o cartaz era uma forma barata e eficaz de comunicação. Estes cartazes, por sua conformação estética, possibilitariam a comunicação, seriam veículo de uma mensagem para as massas. A falta de ornamentos supérfluos, o uso marcante da linha e das formas geométricas, e a posição bem centralizada do objeto anunciado, além do contraste entre as formas geométricas e as cores, que causam um certo impacto visual pensado com o intuito de chamar a visão ao ponto central do cartaz, ao objeto que fica em destaque, todas estas características formais foram usadas com o objetivo de veicular uma mensagem de forma clara e direta. A possível contradição advinda de que esta mensagem estivesse voltada para um mercado e para o consumo, foi devidamente racionalizada como propaganda política, como se pôde ver nas declarações de Maiakovski.

Também decisivo para a adoção da fotografia foi o encontro de Rodchenko com o cinema. Desde 1922 ele trabalhava desenhando o layout de uma revista de cinema editada por Aleksei Gan (1895-1942), Kino-fot, e, de 1922 a 1924, ele trabalhou com Dziga Vertov (1 897-1954) fazendo os letreiros para a série de documentários Kino-Pravda [Cine-Verdade], cinejornais que noticiavam sobre toda a Rússia. Ele passou a fazer parte do grupo Kinoki lacrônimo russo para cine-olhol, de Vertov, entrando em contato com as ideias deste sobre cinema: a valorização do documentário, do registro de cenas urbanas e cotidianas, sem atores ou cenários, e a defesa da visão por meio da câmera, de sua superioridade e supremacia; ou seja, a possibilidade que ela dava de fazer imagens sob pontos de vista tão livres quanto o olho, mas o superando, em função de suas potencialidades técnicas, mostrando o que escaparia à percepção humana. Rodchenko trabalhou os letreiros dos filmes de Vertov com os preceitos recémadquiridos. Segundo Dawn Ades, existem muitos paralelos entre a evolução do cinema russo e da fotomontagem - especialmente no que concerne aos cortes dinâmicos, rápidos, unidade de tempo e espaço constantemente rompidas, comparações e qualificações, alternação entre close-ups e vistas afastadas, duplas exposições, etc ${ }^{88}$.

Algumas das características ressaltadas pela autora são facilmente encontradas nas montagens de Rodchenko, inclusive nas iniciais, como as de Sobre Isso: a quebra de unidade de tempo e espaço, causada pela falta de perspectiva, é uma das mais presentes. Assim, a mútua influência entre montagem fotográfica e montagem cinematográfica pode tê-lo aproximado, ao mesmo tempo, tanto do olhar cinematográfico quanto do olhar fotográfico. Um olhar, porém, que não era passivo, que procurava ser um olhar-agente, ou uma verdadeira câmera-olho, como queria Vertov. A presença marcante deste olho ativo, criativo, foi sintetizada no cartaz que Rodchenko criou para o filme longa-metragem de Vertov, Kino-Glaz
87. Sobre a aparente contradição que poderia ser suscitada por artistas engajados politicamente da vanguarda russa criarem anúncios para a venda de bens de consumo muitas vezes supérfluos, e sobre a relação delicada que existiu entre a arte de vanguarda e a política do partido durante os anos da NEP, ver Christina Kiaer (2005), especialmente o capítulo 4 .

88. Ver Dawn Ades (1976, p. 87). 
89. Ver Margarita Tupitsyn (1998, p. 11)
(Cine-Olho) de 1924 (Figura 6). Esta fotomontagem traz no centro, predominante, a fotografia de um olho humano; abaixo deste olho, que mira o espectador do cartaz, há, saindo dos cantos diagonais em sua direção, duas câmeras; mais abaixo das câmeras, duas imagens espelhadas de um rosto olham na direção da câmera, e, portanto, em direção ao olho. Tanto para Rodchenko quanto para Vertov, este olho, por meio da câmera, ganhava o estatuto ativo de criador de um campo imagético 89 . Ele fazia-se, portanto, um aparato discursivo, que deveria dar conta da nova sociedade que se tornava mais complexa, que se queria mais moderna. Para estes vanguardistas, apenas um aparato moderno, criador de uma linguagem moderna, poderia dar conta dessa sociedade. Em um artigo de 1923, chamado The Cine-Eyes: a revolution, uma espécie de manifesto dos kinoki publicado em Lef n. 3, Vertov havia escrito:

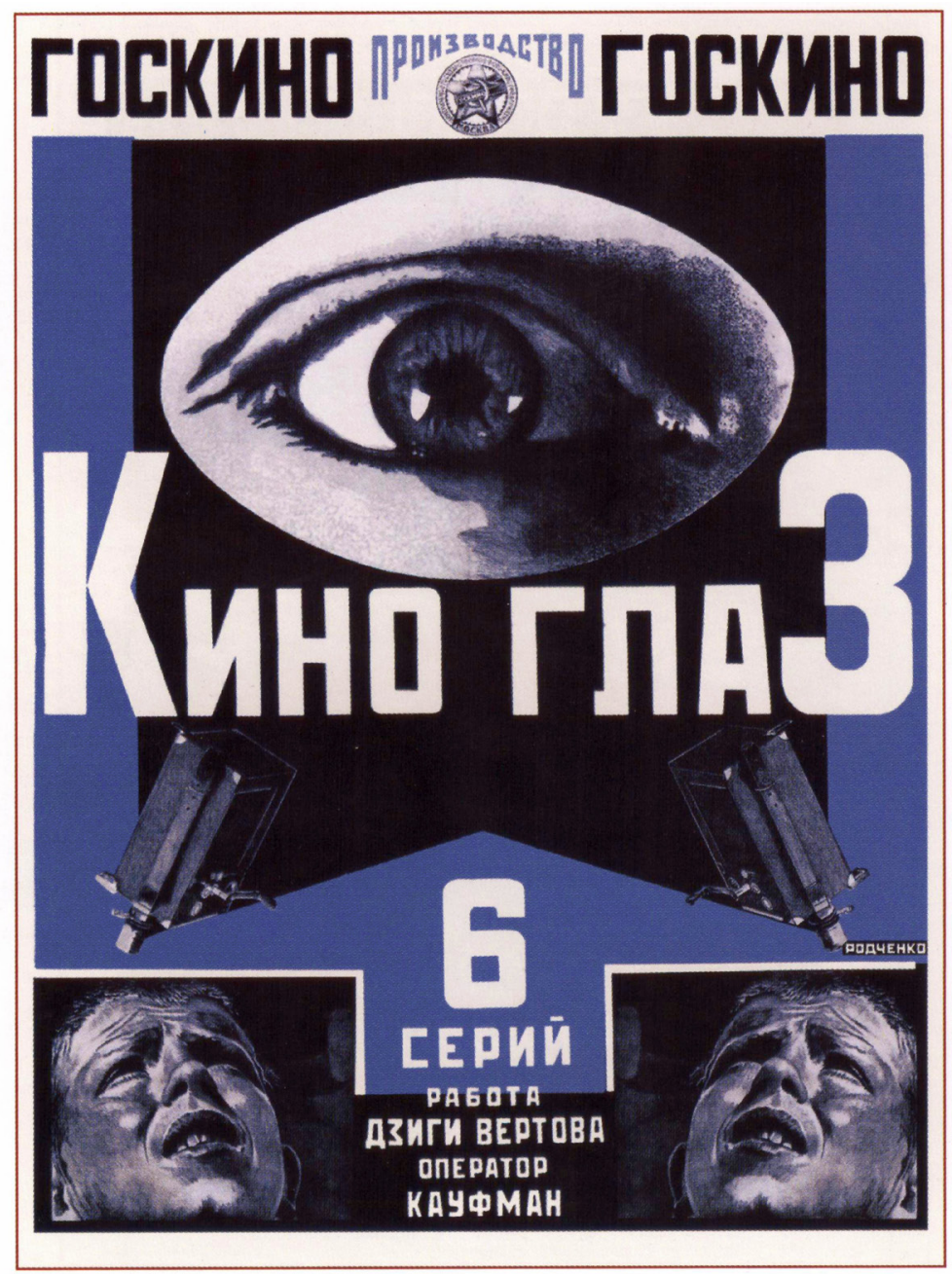

Figura 6 - Aleksandr Rodchenko. Fotomontagem para o filme Kino-Glaz, de Dziga Vertov, 1924. Cartaz. Disponível em : <hitp://en.wikipedia.org/wiki/Dziga_Vertov\#mediaviewer/File:Kino_glaz.jpg>. 
Eu a máquina mostro a você o mundo como apenas eu posso vê-lo.

Eu me emancipo da imobilidade humana de agora em diante e para sempre. Eu estou em constante movimento. Eu me aproximo dos objetos e me distancio deles, eu serpenteio sobre eles, eu os escalo, eu me movo junto ao focinho de um cavalo correndo, eu adentro uma multidão a todo vapor, eu fujo logo a frente de soldados que fogem, eu me viro de costas, eu me ergo com aviões, eu caio e me ergo com corpos caindo e se erguendo.

... Eu sobreponho qualquer ponto do universo independente de onde eu os fixei.

Meu caminho leva em direção à criação de uma nova percepção do mundo. Eu posso portanto decifrar um mundo que você não conhece. ${ }^{90}$

Já na ocasião da feitura de Kino-Glaz, baseado na série de curtasmetragens jornalísticos que Vertov havia realizado nos anos anteriores, o cineasta declarou o notável papel político que este olho-agente possuiria:

Me baseando na difícil experimentação de dezenove Kinopravdas, nós não obstante esperamos (...) abrir os olhos das massas para a ligação (não uma de beijos ou detetives) entre o fenômeno visual e social interpretado pela câmera. ${ }^{91}$

Para Rodchenko, a presença da câmera como uma entidade criadora e discursiva possuía igual apelo, e um intento semelhante ao declarado por Vertov estaria presente quando, em 1924, também ele adotou uma câmera e procurou traduzir suas crenças políticas em matéria visual, por meio de fotografias.

Outro fruto do encontro com o cinema são os dois pôsteres que Rodchenko criou para o filme Encouraçado Potemkin, de 1925, dirigido pelo também construtivista Sergei Eisenstein (1898-1948). Como Vertov, Eisenstein dava grande importância para o processo de montagem em seus filmes. Nos dois casos, havia um diálogo forte com as imagens fixas, principalmente as fotomontagens, mas também as fotografias, criadas pelos colegas construtivistas: assim como a partir do conceito de Vertov de kino-glaz criou-se o foto-glaz, [foto-olho] ou olhar fotográfico, Eisenstein desenvolveu uma teoria e prática mundialmente reconhecidas no âmbito da montagem cinematográfica, mas que possuía elementos da arte construtivista e um forte diálogo com a fotomontagem. Em junho de 1923, mesma época em que Sobre Isso foi publicado, Eisenstein reconheceu, em artigo que saiu na revista Lef, a influência das fotomontagens de George Grosz e Rodchenko - em especial na possibilidade de impacto sobre o público que a separação dos elementos da composição e a reorganização e remontagem destes causaria ${ }^{92}$.

Margarita Tupitsyn considera que apenas em 1928 Dziga Vertov foi capaz de elaborar uma versão da câmera-olho presente no cartaz que Rodchenko havia criado para Kino-Glaz: o longa Um homem com uma câmera ${ }^{93}$. Efetivamente, este filme tem uma correspondência imagética, que não é gratuita, com as fotografias que Rodchenko começou a produzir a partir de 1924. A centralidade da câmera, além de possuir um forte apelo sobre os artistas da vanguarda russa, fazia também parte de um amplo debate teórico e conceitual que se desenrolava
90. Cf. Peter Galassi. In: Peter Galassi; Magdalena

Dabrowski e Leah Dickerman (1999, p. 123), tradução da autora.

91. Cf. Dziga Vertov (1984, p. 35).

92. Victor Margolin (1998, p. 106-108).

93. Margarita Tupitsyn (1998, p. 9). 
94. Sobre isso, ver os Capítulos 3 e 4 de Erika Zerwes (2008).

95. Christina Lodder (2000, p. 293).

96. Cf. Douglas Crimp (2005, p. 232). na década de 1920. Devido ao engajamento destes artistas, suas opções estéticas e seu próprio método criativo que, dentre outras obras da vanguarda, culminaram tanto com as fotografias de Rodchenko, como também com o filme de Vertov de 1928, traziam materializados os conceitos desenvolvidos pela linguística russa, como a evidência do aparato defendida por Roman Jakobson, e os preceitos teóricos da união entre o material do qual é feita e a forma da obra de arte, entre outros, defendidos pelo LEF94.

As fotografias que Rodchenko começou a fazer em 1924 têm assim correspondência com todas as experimentações artísticas pelas quais transitou, e os enquadres, a posição da câmera, a própria linguagem imagética destas fotografias, demonstra maior afinidade e diálogo com o cinema construtivista de Dziga Vertov e Eisenstein ${ }^{95}$.

\section{Conclusão}

Em 1924, com seis retratos de Maiakovski, Rodchenko dedicou-se pela primeira vez ao processo completo da fotografia: sua elaboração, seu registro e seu processamento - era ele quem as revelava e copiava - até a obtenção da imagem no papel. No entanto, longe do meio fotográfico ser encarado por ele como uma ruptura com as intenções das experimentações que moveram a sua produção artística anterior, a fotografia manteve-as e as desenvolveu ainda mais.

Falar da fotografia de Rodchenko sem mencionar este período anterior é, portanto, compreender apenas em parte suas intenções com ela. Fica claro, portanto, porque Douglas Crimp retoma a questão já levantada por Benjamin Buchloh, sobre a forma - para eles problemática - com que o MoMA de Barr Jr. exibiu obras das vanguardas do entreguerras utilizando a obra de Rodchenko como um exemplo privilegiado. Buchloh, e depois Crimp, apontaram para uma leitura enviesada por parte do museu, que teria falhado em apresentar corretamente a arte vanguardista, e que "nunca esclareceu completamente a posição histórica da vanguarda"96.

Ao entrecruzar seus experimentos artísticos e o que considerava como demandas políticas da sociedade soviética, bem como respondendo às declarações e diretivas do Partido, o caminho que Rodchenko percorreu com as artes tradicionais foi um progressivo libertar-se da representação realista, como pôde ser observado mais acima: com a valorização da factura, o caráter iconográfico foi aos poucos sucumbindo, até ser exterminado no tríptico de telas da exposição $5 \times 5=25$ de 1921. A partir daí, porém, o movimento foi inverso. A passagem para a fotomontagem reabilitou de certa forma a representação na sua arte. Era, porém, uma representação ainda carregada de factura e também do não figurativo. Apenas com a adoção da fotografia, o iconográfico foi trazido definitivamente de volta, mas construído por uma máquina, cuja imagem, para os artistas e teóricos do LEF, não tentava se assemelhar ao real, e sim ofereceria um registro verídico, e impresso em papel, para o uso que thes aprouvesse. 
Como o texto Fotomontagem, publicado em 1924 na revista Lef, afirmou "Esta precisão e caráter documentário do instantâneo tem um impacto no observador que uma representação gráfica jamais irá alcançar"97. A retomada de uma arte representacional teria, portanto, uma relação declarada com a propaganda por meio de seu caráter documental - da fidelidade que seu registro mantinha, na opinião dos artistas que a praticavam - com o real. Para grande parte dos artistas engajados com a fotomontagem, a arte possuiria um papel ativo dentro da sociedade socialista e deveria ser feita por meio, e com a finalidade de alcance, das prerrogativas da sua construção.

Em nome da modernização, muitos intelectuais, pesquisadores e políticos da União Soviética, e teóricos ligados à arte de vanguarda e em alguns casos ao LEF, como Boris Arvatov, Boris Kushner e Aleksei Gastev, acreditavam que a sociedade como um todo deveria ser organizada tal qual uma fábrica que seguisse o modelo taylorista, e a arte deveria, portanto, estar acessível às massas para que pudesse as orientar nesta organização. A arte teria mesmo um papel pedagógico. Assim, o retorno à representação, prenunciada pela fotomontagem e realizada pela fotografia, teria sido fruto de uma demanda política, com o intuito de, por meio de uma arte mais inteligível às massas, estabelecer contato com elas. Um contato com fins publicitários: indo da pintura carregada de factura para uma factográfica fotografia, ou seja, um meio que, embora icônico - porque retratava de forma realista o mundo - não era pictórico, pois não deixava aparente a mediação da mão do artista, como era o caso da pintura. Segundo Buchloh, esta passagem da factura - que foi elemento fundamental do paradigma moderno presente na vanguarda soviética até os primeiros anos da década de 1920 - para a factografia ligada às características técnicas da imagem fotográfica, veio com a crença na possibilidade desta imagem retratar de forma absolutamente fiel e sem mediações o mundo real. $\bigcirc$ autor ressalta que, neste sentido, pode-se compreender melhor a nova fase artística que Rodchenko inaugura em 1924, quando deixa de lado a produção de fotomontagens para dedicar-se à fotografia propriamente. Longe de abandonar as diretrizes teóricas que seguia antes, no entanto, Rodchenko incorporará muitas das noções estéticas e efeitos visuais buscadas na fotomontagem no próprio ato fotográfico - a montagem presente em suas fotografias se realizará por meio de enquadramentos, ângulos de visão e posicionamento da câmera, das escolhas técnicas ${ }^{98}$.

Como também em outras oportunidades, a opção estética e criativa de Rodchenko, que neste momento o levava para a fotografia, estaria assentada em suas filiações políticas.
97. Cf. Christopher Phillips (1989, p. 211-212), tradução da autora.

98. Benjamin H. D. Buchloh (1984, p. 64), tradução da autora. 


\section{REFERÊNCIAS}

ADES, Dawn. Photomontage. Londres: Thames and Hudson, 1976.

(Org). The 20th-Century Poster. Design of the Avant-Garde. Nova York: Abbeville Press, 1984.

BAROOSHIAN, Vahan D. Russian Cubo-Futurism 1910-1930: A Study in Avant-Gardism. Haia: Mouton, 1974.

BARR Jr., Alfred. Russian Diary: 1927-28. October, v. 7, winter 1978.

Cubismo y arte abstracto: introducción. In: La definición del Arte Moderno. Madri: Alianza Editorial, 1989.

BENJAMIN, Walter. Rua de mão única. São Paulo: Brasiliense, 1995. (Obras escolhidas, v.2).

BOLTON, Richard (Org). The Contest of Meaning: Critical Histories of Photography. Cambridge: MIT Press, 1992.

BOWLT, John E. (Org). Russian Art of the Avant-Garde: Theory and Criticism 1902-1934. Londres: Thames \& Hudson, 1988.

BOWLT, John E.; MATICH, Olga (Ed.). Laboratory of Dreams: The Russian Avant-Garde and Cultural Experiment. Stanford: Stanford University Press, 1996.

BUCHLOH, Benjamin H. D. From Faktura to Factography. October, Cambridge, v. 30, autumn 1984.

BUCK-MORSS, Susan. Dreamworld and Catastrophe: The Passing of Mass Utopia in East and West. Cambridge: MIT Press, 2002.

CRIMP, Douglas. Sobre as ruínas do museu. São Paulo: Martins Fontes, 2005.

DICKERMAN, Leah. Aleksandr Rodchenko's Camera-Eye: Lef Vision and the Production of Revolutionary Consciousness. Tese (Doutorado em Filosofia) - University of Columbia, Nova York, 1997.

Camera Obscura: Socialist Realism in the Shadow of Photography. October, Camobridge, v. 93, summer 2000.

DIDI-HUBERMAN, Georges. O que vemos, o que nos olha. São Paulo: Editora 34, 2005.

EGBERT, Donald Drew. The Idea of Avant-Garde in Arts and in Politics. The American Historical Review, Richmond, v. 73, n. 2, Dec. 1967.

El arte en la teoria marxista y en la practica sovietica. Barcelona: Tusquets Editor, 1973.

FABRIS, Annateresa. Um olhar sob suspeita. Anais do Museu Paulista, v. 14. n. 2, jul./dez. 2006.

FER, Briony; BATCHELOR, David; WOOD, Paul. Realismo, Racionalismo, Surrealismo: a arte no entre-guerras. São Paulo: Cosac \& Naify, 1998. 
FRIZOT, Michel (Org). The New History of Photography. Colônia: Köneman, 1998.

GASSNER, Hubertus. The Constructivists: Modernism on the Way to Modernization. In: The Great Utopia: the Russian and Soviet avant-garde, 1915-1932. Nova York: Guggenheim Museum, 1992. Catálogo de exposição.

GRAY, Camilla. The Russian Experiment in Art: 1863-1922. Londres: Thames and Hudson, 2000 .

HUGUES, Robert. The Shock of the New. Nova York: Alfred A. Knopf, 1995.

KHAN-MAGOMEDOV, Selin O. Rodchenko: The Complete Work. Londres: Thames and Hudson, 1986.

KIAER, Christina. Imagine no Possessions. The Socialist Objects of Russian Constructivism. Cambridge: MIT Press, 2005.

LAVRENTIEV, Alexander (Org). Aleksandr Rodchenko: Experiments for the Future. Nova York: Museum of Modern Art, 2005.

LAWTON, Ana; EAGLE, Hebert. Words in Revolution: Russian Futurist Manifestoes: 1912-1928. Washington: New Academia Publishing, 2004.

LE GOFF, Jacques. Memória e história. Campinas: Editora da Unicamp, 1996.

LÊNIN, V. I. Escritos sobre la literatura y el arte. Barcelona: Ediciones Península, 1975.

LODDER, Christina. Russian Constructivism. New Haven: Yale University Press, 1987.

Promoting Constructivism: Kino-fot and Rodchenko's Move into Photography. History of Photography, v. 24, n. 4, winter 2000.

MAIAKOVSKI, Vladimir. Isso. In: Gráfica utópica: Arte Gráfica Russa: 1904-1942. Brasília: Centro Cultural Banco do Brasil, 2002. Catálogo de exposição.

MARGOLIN, Victor. The Struggle for Utopia: Rodchenko, Lissitzky, Moholy-Nagy: 1917-1946. Chicago: University of Chicago Press, 1998.

NADRA, Fernando. O novo homem soviético. Moscou: Edições Progresso, 1983.

NEWHALL, Beaumont. The History of Photography. Nova York: Bulfinch Press; MoMA, 2002.

PETER, Galassi; DABROWSKI, Magdalena; DICKERMAN, Leah. Aleksandr Rodchenko: Painting, Drawing, Collage, Design, Photography. Nova York: Museum of Modern Art, 1998.

PHILLIPS, Christopher (Org). Photography in the Modern Era. Nova York: The Metropolitan Museum of Art; Aperture, 1989.

RANCIÈRE, Jacques. A partilha do sensível. São Paulo: Editora 34, 2005.

SCHNAIDERMAN, Boris. A poética de Maiakóvski através de sua poesia. São Paulo: Perspectiva, 1971. 
TUPITSYN, Margarita. Beyond Formalism: The Function of the Soviet Photograph: 1924-1937. Tese (Doutorado) - City University of New York, Nova York, 1996. exposição.

Aleksandr Rodchenko: the New Moscow. Lisboa: Schirmer; Mosel, 1998. Catálogo de The Histories of the Soviet Photograph at Home and Abroad. History of Photography, v. 24, n. 4, winter 2000 .

VERTOV, Dziga. On the Film Kino-Glaz. In: Kino-Eye: The Writings of Dziga Vertov. Berkeley: University of California Press, 1984.

ZERWES, Erika. A fotografia eloquente: arte e política em Aleksandr Rodchenko, 1924-1930. Dissertação (Mestrado) - IFCH-UNICAMP, Campinas, 2008.

Artigo apresentado em 11/09/2014. Aprovado em 09/04/2015. 